GEOLOGICAL SURVEY CIRCULAR 741

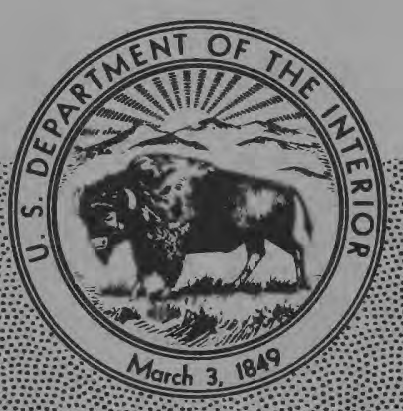




\section{Oil Spills, 1971-75, \\ Gulf of Mexico \\ Outer Continental Shelf}

By Elmer P. Danenberger

GEOLOGICAL SURVEY CIRCULAR 741

Statistics and discussion of oil spills resulting from offshore operations on Federal oil and gas leases in the Gulf of Mexico 


\section{United States Department of the Interior}

THOMAS S. KLEPPE, Secretary

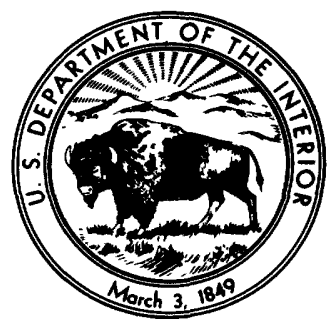

\section{Geological Survey}

V. E. McKelvey, Director 
Page

System of measurement units $\ldots \ldots \ldots \ldots \ldots \ldots$ IV

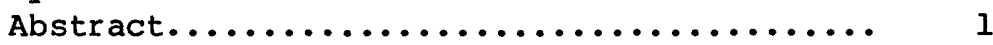

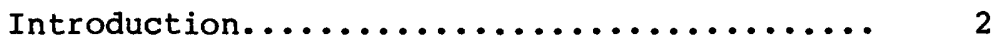

Sources and reliability of data........... 5

Major spills..................... 7

Minor spills...................... 10

Production-platform spills........... 12

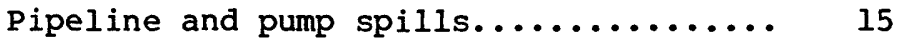

Spills of less than 1 barrel.......... 16

Production incidents, by operator...... 17

production incidents, by platform...... 18

Other sources of spillage.............. 19

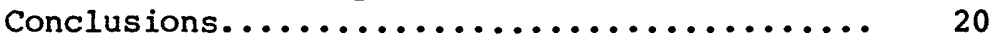

Selected references................... 22
\end{abstract}

Page

Figure 1. Index map showing Outer Continental Shelf leasing areas in the Gulf of Mexico off Texas and Louisiana....... 27

2. Bar graph showing number and volume of 1- to 50-barrel

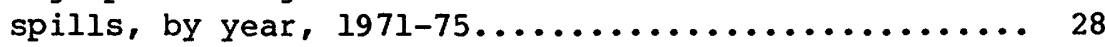

3. Schematic diagram showing casing program and production safety system of a typical 12,000-foot-deep well, Gulf of Mexico.......................... 33

4. Simplified flow diagram for offshore oil and gas

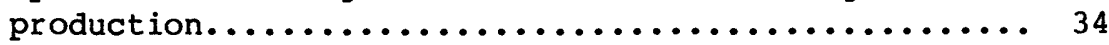

5-10. Bar graphs showing:

5. Number and volume of 1- to 50-barrel spills, by year, 1971-75, for production platforms and for pipelines and pumps............... 35

6. Principal causes of production-platform spills of 1-50 barrels, by year, 1971-75........ 37

7. Principal causes of sump-system spills of $1-50$ barrels on production platforms, by year,

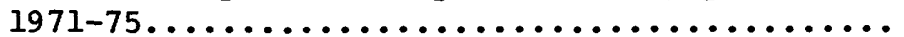

8. Number of 1- to 50-barrel spills involving failure of high-low level controls on production platforms, by year, 1971-75........

9. Principal causes of pipeline and pump spills of 1-50 barrels, by year and volume of spills,

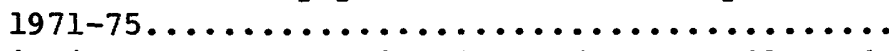

10. Principal causes of pipeline and pump spills of 1-50 barrels, by year and number of spills,

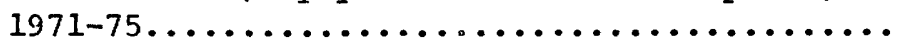


Figure 11. Graph showing comparison, by year, of the number of structures having spills with the total number of

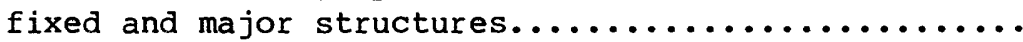

12. Bar graph showing estimated volumes of petroleum hydrocarbons introduced annually into the world's oceans, in millions of metric tons..............

\section{TABLES}

Page

Table 1. Annual production of oil and condensate from all operations on the Outer Continental Shelf, 1971-75.......

2. Number and volume of spills each year, 1971-75, Gulf of Mexico Outer Continental Shelf............... 29

3. Causes of oil spills of more than 50 barrels, 1971-75.. 30

4. Causes of oil spills of 1-50 barrels, 1971-75........ 30

5. Oil spills of more than 1,000 barrels, $1971-75 \ldots \ldots \ldots .31$

6. Blowouts resulting in pollution, casualties, or

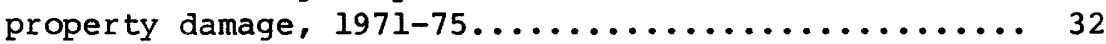

7. Causes of 1- to 50-barrel spills on production

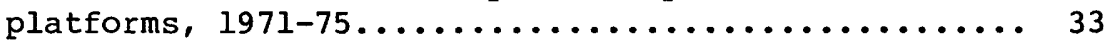

8. Causes of 1- to 50-barrel spills on production platforms, 1971-75, grouped according to system that failed............................ 36

9. Causes of 1- to 50 barrel spills from pipelines and

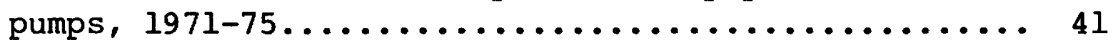

10. Frequency of spills among production platforms having at least one 1- to 50-barrel spill during 1971-75... 42

11. Production-platform spills of 1-50 barrels, identified by operator, $1971-75 \ldots \ldots \ldots \ldots \ldots \ldots \ldots .45$

12. Budget of petroleum hydrocarbons into the oceans...... 47

SYSTEM OF MEASUREMENT UNITS

[The following report uses the English system of units. The English units can be converted to metric units by multiplying by the factors given in the following list]

ro convert

English unit

Acres......................

Barrels (oil).................

Barrels $\left(36^{\circ}\right.$ API oil) ............

Cubic feet....................

Feet........................

Miles, statute.................

geographical or nautical...

Square miles, statute............

$\begin{array}{ll}\text { Multiply by } & \begin{array}{l}\text { To obtain } \\ \text { Metric unit }\end{array} \\ 0.4047 & \text { Hectares (ha). } \\ 4.047 \times 10^{-3} & \text { Square kilometers }\left(\mathrm{km}^{2}\right) . \\ 0.159 & \text { Cubic meters }\left(\mathrm{m}^{3}\right) . \\ 1.590 \times 10^{2} & \text { Liters }(1) . \\ 0.1342 & \text { Metric tons. } \\ 2.832 \times 10^{-2} & \text { Cubic meters }\left(\mathrm{m}^{3}\right) . \\ 28.32 & \text { Liters }(1) . \\ 0.3048 & \text { Meters }(\mathrm{m}) . \\ 1.609 & \text { Kilometers }(\mathrm{km}) . \\ 1.852 & \text { Kilometers (km). } \\ 2.590 & \text { Square kilometers }\left(\mathrm{km}^{2}\right) .\end{array}$


Oil Spills, 1971-75, Gulf of Mexico

Outer Continental Shelf

By Elmer P. Danenberger

ABSTRACT

Oil spillage connected with federally supervised drilling and production activities has been a matter of wide public concern. In its supervision of mineral-resource development on the Outer Continental Shelf (OCS), the U.S. Geological survey is responsible for the day-to-day inspection and monitoring of OCS oil and gas operations. During these activities, the U.S. Geological survey records and investigates hydrocarbon discharges resulting from such operations. Beginning in 1971, all spills have been recorded, and a computer file has been maintained on all spills of 1 barrel or more.

The total Gulf of Mexico ocs oil spillage recorded during January 1 , 1971-December 31, 1975, amounted to 51,421 barrels. Production during that period amounted to 35,219 barrels per barrel spilled. In all, 5,857 spills were recorded, but 85.5 percent of the total spill volume was contributed by just 5 incidents. The environmental effect of these incidents apparently was minimal and of short duration. No spills of more than 50 barrels resulted from drilling operations during the period. The only spillage resulting from blowouts was caused by nondrilling incidents, including completion, production, and workover.

The amount of oil discharged from spills of less than 50 barrels decreased by more than half between 1971 and 1975. The improvement reflects changes in the operating philosophy of the offshore industry, tightening of U.S. Geological survey operating orders, and substantial increases in the inspection force. Most production-platform spills involve 
failures in the sump system, the separator system, or other hydrocarbonhandling equipment; improved sump-system designs and better high-low-level controls have reduced both the number and the volume of spills. Pipeline and pump spills also declined significantly, although the decline appears less attributable to revisions in ocs operating requirements. No operator consistently contributed a disproportionate amount of spillage. Most of the platforms having production spills had only one spill during the period. Of the 304 platforms having incidents, 255 had 2 spills or less and 188 had only 1 spill.

Comparison of the volume spilled with the volume produced for Gulf of Mexico OCS operations during 1971-75 results in a spillage rate of 0.0028 percent. Spillage from tankers is estimated to be greater. The ocs drilling and production spillage rate is not expected to increase during exploration and development of the frontier areas.

\section{INTRODUCTION}

The Department of the Interior is authorized by the Outer Continental Shelf Lands Act of August 7, 1953, to grant mineral leases on Outer Continental Shelf (OCS) lands and to prescribe such regulations as might be necessary to carry out the provision of the act. After the 1973 oil embargo, in response to calls for "energy self-sufficiency," the Department expanded its Outer Continental Shelf oil and gas leasing program. The Bureau of Land Management has tentatively scheduled lease sales for 17 areas before 1979. Thirteen of these areas have not yet been evaluated by exploratory drilling and are considered "frontier" (unexplored) areas. Public opinion toward these leasing programs ranges from expectation to apprehension and distrust; the concern arises from such matters as the likelihood of oil spills and the impact of these spills on the marine environment, valuable estuaries, commercial fishing, and tourism. This report summarizes statistics on oil spills during 1971-75 in the Gulf of Mexico and discusses the causes of these incidents and the damage that resulted.

The Gulf of Mexico (fig. 1) is now and has been for 30 years the world's most active offshore oil and gas area; since 1947, almost 13,000 
wells have been drilled in Federal waters. During 1971-75, more than 1.8 billion barrels of oil and condensate were produced from Federal lands in the Gulf (table 1); this was more than 10 percent of the nation's domestic crude oil production and approximately 15 percent of the natural gas production. At the end of 1975, approximately 65 mobile drilling units were operating in the Gulf in water depths as great as 1,775 feet. Oil and gas are currently being produced from 2,079 platforms in waters up to 373 feet, and a steel tower is being constructed for a Gulf of Mexico site in water deeper than 1,000 feet. Subsea production systems, deepwater guyed towers designed to yield slightly to environmental forces, and other prototype equipment that are now being tested in the Gulf will greatly increase the capability of offshore development.

Although both onshore and offshore oil and gas operations were pioneered and developed in this country, few Americans are acquainted with actual oil and gas development practices, and some have misconceptions about the conduct of such operations. Oil spillage is a particularly emotional topic and can readily be misunderstood or distorted. The errors can arise from numerous sources. Study teams, though lacking sufficient statistical data, may seek to apply historical data to projections of spill estimates for "frontier areas." Definitions and statistics can intentionally be presented so as to generate an intended result. oil-spill forecasts for frontier areas--especially difficult to make--may be influenced more by the forecaster's prejudices and understanding of the statistics than by the historical record. Interchanging statistical information from many different sources can lead to unreasonable conclusions. In some instances, frontier-area oil-spill forecasts have been expressed as high and low estimates for spills of several categories (such as drilling, production, and transportation). Addition of the high (maximum) estimates for each category gives unrealistically high estimates for total spillage. Other annual spillage forecasts are based on peak annual production for the oil field under consideration; multiplication of this maximum annual estimate by the anticipated years of production from the field gives an inordinately high estimate for total spillage. Similarly, some projected studies do not take into consideration technical 
innovations that will be introduced, and other studies overcompensate for future improvements.

The absence of universally recognized definitions for such terms as "major spill," "minor spill," and "blowout," allows considerable latitude in categorizing incidents. One observer could justifiably say that there has only been 1 major pollution incident in the history of ocs operations, whereas another might with equal validity cite 30 incidents.

In its capacity as manager of leased lands on the OCS, the U.S. Geological Survey issued, effective August 28, 1969, OCS Order No. 7. This Order establishes pollution-prevention and waste-disposal requirements and requires that all spills, regardless of size, be reported to the U.S. Geological Survey. After issuance of this Order, the Survey significantly increased its field inspection staff and its contracted helicopter fleet, which enables regular, frequent inspection flights. The reporting requirements and the staffing increases were essential to establishing complete data on oil spills.

The first full year, 1970, of applicability of ocs order No. 7, which established the requirements for reporting and recording spills, disclosed various shortcomings of the procedures. Reports on some spills were expressed in general terms such as "minor spill," rather than as the "best estimate" of the quantity spilled, which is essential for statistical analysis. The cause of the spill was not always identified or accurately recorded. Spill data for periods prior to 1971 are, therefore, of limited value, especially for minor spills. By the end of 1970, most of the spillreporting problems had been resolved.

The historical record on oil spills is utilized to forecast discharges in frontier areas, despite the questionable applicability, and such statistics provide one means of evaluating offshore oil and gas operations. Complete statistics on hydrocarbon discharges are maintained by the U.S. Geological Survey, in its role of supervising OCS oil and gas operations. Because of the public interest, these data are presented here for the years 1971-75, for which statistics are complete. 
Safety and pollution prevention are two major objectives of the U.S. Geological Survey OCS Lease Management Program. Meeting the objectives required establishing an effective oil-spill and accident-report data base. At the request of the Survey's Director, the Water Resources Division reviewed the Conservation Division's Lease Management Program; this study (U.S. Geological Survey, 1972) led to development of an OCS Events File, which utilizes the General Information Processing system (GIPSY), an information-handling tool developed at the University of Oklahoma. This computer file, which is updated monthly, encompasses information on all spills of 1 barrel or more, blowouts, fires and explosions, fatalities, and miscellaneous accidents; the data for each incident consist of date, location, type of operation, probable causes, and a brief description of the event.

The compilation of spill data, by cause, presented in tables 3, 4, and 7-9, is derived from the ocs Events File. The annual breakdown of oil spills by size (table 2) was compiled from the monthly reports on Gulf of Mexico OCS operations. For spills of 50 barrels or more, the total number and volume of spills as compiled from the Events File (table 3) correlates precisely with the more-than-50-barrel-spill totals from table 2 .

Table 4, derived from the ocs Events File, shows 872 spills of 1-50 barrels. Fifteen of those incidents are in both the pipeline and production-platform categories. Another seven spills were each 50 barrels, resulting in an actual Events File count of 850 incidents involving 1-49 barrels. These compare with 887 such incidents compiled manually from the operations reports. The two data sources agree within 1 percent on a volume-spilled basis.

The above figures indicate that the two data sources agree and that virtually every incident has been recorded in the Events File. How well are oil-spill incidents being reported? The reporting depends to a large degree on the cooperation of the operators. This reporting is supplemented 
by U.S. Geological Survey inspection and surveillance. At least 10 inspection teams operate daily offshore, weather permitting; for example, during 1975, 3,388 pollution-surveillance flights were made. Any slicks or other indications of pollution are reported immediately by the inspection team, and an attempt is made to identify the source of such discharge. If the pollution is emanating from an offshore production facility, the faulty piece of equipment or the entire platform is shut-in at once. Any willful violators of regulations regarding discharge are subject to criminal prosecution by the Department of Justice.

U.S. Geological Survey field engineers and technicians believe that the offshore operators have been diligent in adhering to the spillreporting requirements of OCS Order No. 7. Although some minor spills may go unreported, an operator has, from a regulatory standpoint, little incentive not to comply with reporting requirements. The enforcement action resulting from a reported minor oil spill is--if there are no aggravating circumstances--an order to shut-in, whereas failure to report an incident could lead to criminal prosecution. The sustained increase in the number of less-than-1-barrel spills reported during 1971-75, in contrast to the declining number of larger spills, supports the contention that spill reporting became more complete during the 5 years.

Many of the oil slicks detected in the Gulf of Mexico are not related to oil and gas operations but result from discharges from tankers, commercial fleets, natural seeps, and other unrelated sources (table 12).

Determining the amount of oil spilled can be difficult. In many instances, the volume of the spill can be accurately determined, by measuring the differentials between successive meters, measuring the volume changes in production-equipment contents, knowing the flow rates into the various pieces of platform equipment and the overflow period, and other means of detecting losses.from the closed-production system. Volumes discharged from blowouts commonly can be estimated from production history (if available), well tests, and other reservoir data. If no precise means of measuring is available, the quantity discharged can be estimated from the size and appearance of the slick. For example, a barely discernible slick might contain only 25 gallons of oil per square mile, whereas a dark- 
brown slick could amount to more than 1,300 gallons per square mile. The estimate must also take into consideration natural processes acting upon the spill, such as weathering, solubility, emulsification, and biodegradation. Therefore, the reliability of visual estimates is low, and estimates on 1 spill can vary by 100 percent or more. In the past, no effort has been made to evaluate the precision of the discharge estimate. A means of rating the objectivity of an estimate on a scale of 1 to 10 is being considered, whereby a precise volume determined from meter differentials would receive an accuracy rating of 10 , and a rough estimate based on the size and appearance of the slick would be rated as 1 . This scale would provide a clearer picture of the accuracy of the volumetric determinations and would allow maximum- and minimum-discharge calculations based on the best estimates of spillage.

\section{MAJOR SPILLS}

The total Gulf of Mexico OCS oil spillage recorded during 1971-75 was 51,421 barrels (table 2). Gulf of Mexico OCS oil and condensate production during the 5 years totaled 1.811 billion barrels (table 1); 1971, 1972, and 1973 were the 3 highest production years in the history of Gulf of Mexico ocs operations. During the 5 years 35,219 barrels were produced per barrel spilled. ' The total value of the oil and gas produced from both the Gulf of Mexico and the Pacific ocs during $1971-75$ was $\$ 14.3$ billion; in that time, the Federal Government received $\$ 13.9$ billion in rentals, royalties, and bonuses--a large share of the revenues generated by ocs operations. The bonuses paid to the Government for the right to explore and develop ocs

\footnotetext{
${ }^{1}$ This spill figure applies only to the Gulf of Mexico OCS. At present the only other offshore production in Federal waters is in the Santa Barbara Channel, where 104.7 million barrels of oil were produced during 1971-75. No spills of more than 50 barrels occurred in the channel during the period. The only chronic discharges are related to oil seeps. Seepage around platform $A$ in the Channel, triggered by the 1969 blowout, continues at a rate of 4-5 barrels per day. Hundreds of natural oil and gas seeps exist in the Channel and discharge an estimated 200-250 barrels per day (Fisher, 1975). The Coal Oil Point area is the most active seep area, venting an average of about 50-70 barrels per day (Allen and Schlueter, 1969).
} 
tracts amounted to $\$ 11.5$ billion, resulting in Government revenues equal to 97 percent of production value.

of the 5,857 spills recorded during the 1971-75 period, just 5 spills contributed 85.5 percent of the total volume spilled (table 5). A single incident--the Bonita pipeline break in April 1974--accounts for 38.6 percent of the total volume. Success in oil-spill prevention during a particular year, from a volumetric standpoint, depends almost entirely on preventing big spills. Of course, the oil-spill record cannot be evaluated merely from the total volumes discharged. The number of events, the cause and severity, and the intermediate- and long-term trends must be examined. For example, 1974 was the worst of the 5 years in terms of total volume spilled (table 2). However, only 667 barrels was spilled during the year as a result of less-than-50-barrel incidents, the best record of the 5 years. These small spills (discussed later in this report) provide a much better yardstick of the effectiveness of operating requirements, of the equipment that is prone to failure, and of changes in offshore "housekeeping" and spill-prevention programs.

Furthermore, the effect of equivalent-volume spills varies widely, depending on the physical and chemical composition of the petroleum, the physiography of the area, weather conditions at the time of the spill, the biota of the area, the time of year, previous exposure of the area to oil, exposure to other pollutants, and the treatment of the spill (Straughan, 1972).

Petroleum is a complicated mixture of compounds which contain hydrogen and carbon as the principal elements. Crude oils and their byproducts have amazingly complex physical and chemical properties that influence the manner in which they interact with the environment. Recent investigations by Anderson (1975) and the Battelle Pacific Northwest Laboratories (1973) show crude oils to be significantly less toxic than are refined products. This difference accounts in part for the minimal environmental damage recorded from ocS operations spills. Significant damage resulted from only one incident on the Outer Continental Shelf, the January 1969 blowout at platform $A$ in the Santa Barbara Channel, and, apparently, the impacts were short lived. A study conducted by the Allan Hancock Foundation, University 
of Southern California (Straughan, 1971), found that flora and fauna in the Channel were damaged much less than had been predicted, and that the area is recovering well. The only environmental damage recorded as a result of the 5 largest spills in the Gulf of Mexico (table 5) during the 5 years occurred when minor amounts of oil intermittently reached approximately 1,000 feet of beach on the Chandeleur Islands after the September 9, 1974, Cobia pipeline break. On only two occasions prior to 1971, both in 1970, did minor amounts of oil reach the coastline after Gulf of Mexico ocs oil spills. Few bird deaths or other obvious forms of environmental damage have been attributed to OCS oil and gas operations in the Gulf.

Four of the five spills in 1971-75 which exceeded 1,000 barrels were related to transportation of oil from ocs production facilities (table 5). of the 20 spills of more than 50 barrels (table 3), 9 were transportation incidents, and 6 were caused by failures in production-platform equipment. of course, production-platform operations and transportation activities span the entire range of regular offshore-production activities and can, logically, be expected to account for most of the spillage. Spills of 50 barrels or more yielded 90.6 percent of the total volume discharged during 1971-75, and 96.0 and 97.1 percent, respectively, for 1973 and 1974. In 1971, 1972, and 1975, when no spill exceeded 500 barrels, the more-than-50barrel spills account, respectively, for only 46.3, 12.7, and 27.2 percent of the total volume spilled.

Particularly noteworthy is that no spills of more than 50 barrels resulted from drilling operations during 1971-75, even though 4,105 new wells were started. No such spill has occurred since July 19, 1965, when 1,688 barrels of crude oil was discharged into the Gulf during a blowout in the Ship Shoal area off the coast of Louisiana. (An oil blowout which began on March 16, 1969, though technically a nondrilling incident, could be classified with the drilling events. The well had been drilled to total depth, and control was lost during completion operations when the rig shifted during a storm; 2,500 barrels was discharged through the tubing.) Furthermore, no spill in excess of 50 barrels has been recorded during exploratory drilling either on the Federal ocs or, to our knowledge, in any other offshore area throughout the world. Nevertheless, exploratory 
drilling is often labeled as environmentally the most hazardous aspect of offshore operations. The record does not support such contentions.

Some analyses of offshore accidents combine all blowouts into one category and assume that they are related to drilling operations. Then the total number of wells drilled during a given period is simply divided by the total number of blowouts, to derive a figure showing wells drilled per blowout. In similar manner, the oil discharged from these blowouts is divided by the number of wells drilled, to obtain a figure showing barrels spilled per well drilled. The resulting figures are misleading, because many of the blowouts and much of the resulting spillage did not result from drilling operations. It is therefore incorrect to use these figures to predict, from a forecast of the number of wells to be drilled, the number of blowouts and the amount of spillage which will result from offshore activity. For frontier areas, where operations may never advance past the exploratory drilling stage, the system of projection is particularly unsatisfactory.

During 1971-75, 22 blowouts occurred during drilling, workover, or production. Nine of the 22 caused significant pollution or property damage. Of the nine (table 6), five were associated with drilling operations. However, the 4 nondrilling incidents were responsible for all 725 barrels of "blowout spillage." According to OCs blowout records, which go back to 1956, only two drilling-related blowouts caused significant oil spills--the Santa Barbara blowout, during which at least 25,000 barrels of oil was discharged, and the previously mentioned July 1965 Gulf of Mexico blowout. The two most serious blowouts in the Gulf of Mexico ocs occurred in 1970 on production platforms and discharged more than 83,000 barrels.

\section{MINOR SPILLS}

The aggregate volume of less-than-50-barrel spills accounts for only 9.4 percent of the total spillage; numerically, 99.5 percent of the spills are in this quantity category. The great number of such spills--5,830 during the 5 years--allows a more detailed statistical analysis and a more reliable observation of trends. The amount of oil discharged from these spills was reduced by 52 percent between 1971 and 1975. Discharges from 1- 
to 14-barrel incidents decreased by 66 percent during that time. If all spills of 1-50 barrels are considered (fig. 2), the reduction in discharge volume between 1971 and 1975 is 70 percent. (Seven spills discharged 50 barrels each.)

Although 1975 Gulf of Mexico OCS oil and condensate production was 19 percent less than in 1971, production facilities have steadily increased. Therefore, reduced production is unlikely to have contributed to the improved oil-spill picture. The number of OCS platforms in the Gulf of Mexico increased from approximately 1,800 at the end of 1970 to 2,079 on December 31, 1975; the total number of completions jumped from 8,667 to 10,274. Despite the production decrease, the increases in surface equipment would increase the failure probability.

The reduction in minor spills is largely attributable to changes in operating and regulatory philosophy as industry and Government responded to public concerns about the environment. Three serious incidents--the Santa Barbara blowout and two major fires in the Gulf of Mexico--occurred sequentially during 1969 and 1970 and drastically affected the conduct of ocs operations. The offshore industry was under the constant scrutiny of legislators, scientists, and other concerned citizens who formerly had given little thought to offshore oil and gas operations. Industry reacted quickly to improve its public image, examining its offshore operating procedures and initiating safety programs to prevent the recurrence of Santa Barbara-type pollution spectaculars.

The abruptly heightened public interest also affected the regulatory role of the U.S. Geological Survey. New operating requirements--in the form of ocs orders pertaining to drilling procedures, subsurface safety devices, platform safety and production equipment, and oil and gas pipelines--were instituted. The inspection force of 7 technicians was increased approximately 700 percent between 1969 and 1975. The total inspection staff including technicians, engineers, and other support personnel increased tenfold. Numerous additional changes were made in U.S. Geological Survey regulatory programs.

OCS Order No. 8, which outlines platform safety and pollution-control requirements, and OCS Order No. 9, which deals with OCS pipelines, were, 
when combined with industry's own efforts, very effective in reducing the number of spills. As shown in table 4, almost 60 percent of the spillage from 1- to 50-barrel incidents is related to production-platform events. The largest number of spills were caused by failures in the sump system, separator system, and other hydrocarbon-handling equipment (table 7).

OCS Order No. 8 reflects the results of a study of all safety systems then in effect and selection of those devices that seemed least susceptible to failure. Redundant systems are required, in many instances. If one piece of equipment fails, all connected equipment is shut-in. Earlier regulations governing ocS production had been general in nature, allowing operators considerable latitude in judgment factors; each company had its own philosophy concerning safety practices and clean operations. Standardization of antipollution and safety procedures has had a leveling effect on all operators. Now each facility must meet the same requirements, regardless of size, distance from shore, value, or other criteria. Figures 3 and 4 show some of the safety equipment which is required on an OCS production platform.

\section{Production-Platform Spills}

Minor production-platform discharges declined during 1971-75; the particularly sharp drop in 1972 corresponds with the implementation of ocs Order No. 8, which became effective on October 30,1970, and allowed 1 year (until October 30, 1971) for full compliance. The number and volume of 1to 50-barrel platform spills decreased by 45.9 percent and 49.3 percent, respectively, during 1972 (fig. 5). Each platform-spills category, including sump and separator systems, well and header system, and other hydrocarbon-handling equipment, showed significant declines in 1972 (fig. 6). The "other hydrocarbon-handling equipment" category primarily comprises surge-tank and production-tank incidents. The spill-volume decline continued through 1975; the number of spills tended to level off in 1975. Between 1971 and 1975, the number and volume of production-platform spills declined by 75.9 percent and 81.6 percent, respectively (fig. 5). The larger reduction in spill volume, as compared with the reduction in number of spills, indicates that the spills which are occurring are smaller and 
possibly that the 1- and 2-barrel incidents are being more diligently reported. This trend is particularly noticeable in 1975 as the number of production-platform and pipeline and pump spills increased slightly, while the volumes continued to decrease.

Most of the production-platform spills are related to failures in the sump system, the separator system, or other hydrocarbon-handling equipment (tables 7,8$)$. Both closed sumps and open-ended sump piles are utilized in the Gulf of Mexico to collect the deck drainage and the produced water. From an environmental standpoint, the closed tanks are generally considered to be preferable. The oil is skimmed from the closed tank and recycled through the low-pressure-separation system, and the water is discharged into the Gulf. Nevertheless, these systems are not problemfree; and if the tanks and sump pumps are too small, heavy rains can cause hydrocarbons to overflow.

The sump piles are generally long pipes or tanks, open at the bottom, that extend well beneath the water surface. Hydrocarbons are skimmed from the tank and rerouted through the production system, while clarified water is discharged into the Gulf. Problems result when a surge of oil from an overflowing piece of production equipment overloads the sump, when sump pumps fail to operate, when heavy rains overload the sump allowing oil to flow from the open end, and when high-level controls fail, allowing the sump to overfill. The open-ended sumps can be particularly troublesome in shallow water because of the reduced hydrostatic head and the increased effect of wave action.

The number of sump-related spills decreased substantially between 1971 and 1974 and increased slightly in 1975 (figs. 6, 7). This improvement is largely a result of operator initiatives stemming from ocs order No. 8 and company policy changes. New closed-tank sumps and combination sump tank-sump pile systems were installed on certain platforms. Effluents containing significant oil concentrations are routed to separate oil sumps. The decline in the "carry under or overfill" incidents reflects these changes. The newer production platforms incorporate more elaborate treatment schemes. On certain large platforms, an oil sump tank collects oil from all pressure drains and pumps it to the production surge tanks. 
The water drains carry fluids to another closed sump tank. The effluent from the drain sump tank is pumped to a dirty-water surge tank. Oil skimmed from this tank is routed to the oil sump. The water is piped to a gas flotation unit, which lowers the oil content below 50 parts per million, and is then pumped to a clean-water surge tank. oil is skimmed from the flotation unit and from the clean-water surge tank and is piped to the oil sump. Water from the clean-water surge tank is finally discharged into the receiving waters through a disposal tube. Obviously, this is an effective and elaborate sump system. Nevertheless, for old platforms which have been using open-ended sumps for years and are producing from fields in their twilight years, requiring installation of such an elaborate system is difficult to justify. Inasmuch as these platforms have been producing for years with no apparent adverse environmental impact and, further, the costs of installing elaborate drainage-treatment systems could significantly reduce ultimate resource recovery, the U.S. Geological Survey has not required extreme changes in these systems. Proposed Environmental Protection Agency regulations pursuant to the Federal water Pollution Control Act do, however, specify that deck-drainage discharges meet the same oil limitations which apply to produced waters.

The major single cause of spills in the separator system and other hydrocarbon-handling equipment is the failure of high-level controls (table 8 ). The internal float devices required by ocs order No. 8 are designed to automatically shut-in production when the tank fills to a specified level. During 1971-75, 126 spills in the 1- to 50-barrel category involved high-low level control failures. However, the number of these spills has declined sharply (fig. 8). Order No. 8 requires operators to submit to the U.S. Geological Survey semiannual records showing the present status and past history of each device including dates and details of inspection, testing, repairs, adjustment, and reinstallation. Testing of high-level controls may be difficult; in many separators and production vessels, filling the tank is required to activate and test the high-level controls, a time-consuming procedure. Because of the number of items which must be inspected, conducting this test may be impractical for operators and inspectors, and the test is often bypassed. In recent years, many 
operators have been installing high- and low-level sensors in external columns that can be isolated from the vessel. This isolation permits the devices to be tested without interrupting production. The increase in these external controls probably contributed significantly to the decline in spills resulting from high-low level control failures. The revised version of OCS Order No. 8 requires that operators install the sensors in external columns unless solids deposition or foaming hinders activation of the device.

Much of the reduction in production-equipment incidents is attributed to the implementation schedule of ocs order No. 8. Operators were given only 3 months from the October 30, 1970, effective date to comply with most of the provisions regarding automatic shut-in valves, pressure- and liquid-level sensors, and sump systems. Because of the short time allowed, much of the equipment was installed hastily and unsatisfactorily. Once the facilities were equipped to meet the Order's requirements, many of the systems were redesigned, and neater, more effective components were installed. The spill statistics reflect these improvements.

\section{Pipeline And Pump Spills}

The decline in pipeline and pump incidents (fig. 5) is not so clearly attributable to revisions in the ocs Orders. Although OCS Order No. 9, "Oil and Gas Pipelines," which became fully effective in early 1971, undoubtedly contributed to the sharp decline in incidents during 1972, most of the improvement appears to be related to better platform management. In 1972 the total number and volume of these incidents dropped 30.6 and 40.0 percent, respectively, from 1971 levels. The respective declines between 1971 and 1975 were 56.9 and 64.6 percent. The major causes of pipeline and pump spills (table 9; fig. 9) are (1) pipeline ruptures and breaks, (2) pipeline pump failures, (3) discharge or transfer line ruptures or coupling failures, and (4) miscellaneous incidents. Improvement in the latter two categories (figs. 9, 10) is primarily responsible for the sharp reduction in pipeline and pump spills between 1971 and 1975. Improvements in these two categories are probably more directly related to "good housekeeping" than to ocs order No. 9. Because many of the pipelines in the Gulf of 
Mexico are old, a significant reduction in minor pipeline leaks could not be expected to result from implementation of order No. 9. Improvement is expected as inspection programs improve and as advanced cathodic protection and monitoring systems are used.

There is also no indication of a consistent decline in events related to pump failures. Half the 42 pump spills (table 9) resulted from mechanical failures (seal, housing, packing, or piston head burst; union or plunger failed). One-fourth the pump spills also involved high-level control failures. When a pump is deactivated, the production vessel which precedes the pump in the flow scheme--normally a surge or storage tank--may begin to overfill. When the fluid in the tank exceeds a specified level, the high-level float required by ocs order No. 8 should automatically shutin the incoming production. Therefore, 10 of the pump spills could have been prevented had the high-level control operated properly. In three other instances, the high-level control was activated, but a surface safety valve on one of the wells failed, allowing production to continue.

Even though the number of pump spills has not steadily declined (fig. 10), the low number of these spills--2 in 1974 and 4 in 1975--relative to the tremendous volumes of hydrocarbons being handled indicates the general success of the equipment. Three of the 1975 incidents occurred because hydrocarbons continued to flow through damaged pumps when a plate loosened, when a plunger broke, or when a face gasket blew. Only 1 of the 1975 pump spills involved the failure of a high-level control.

\section{Spills of Less Than 1 Barrel}

The less-than-1-barrel spills were the only group to steadily increase during 1971-75 (table 2). These spills increased by 15 percent between 1971 and 1974 and decreased slightly in 1975. Much of this increase can probably be traced to more conscientious interpretation of ocs order No. 7, which requires that operators report all spills. Operators are now very diligent in their observance of this requirement, sometimes reporting spills as small as 1 pint. Statistics are not maintained on the total volume discharged in spills of less than 1 barrel. For record- 
keeping purposes, it is assumed that one-fourth barrel (10.5 gallons) is discharged in each incident. Inasmuch as many of the incidents involve several gallons or less, this volumetric approximation probably represents a maximum figure for these spills.

\section{Production Incidents, By Operator}

Table 11 identifies, by operator, production-platform spills of 1-50 barrels. This limited analysis is one means of evaluating the effectiveness of regulatory changes and modifications in platform-management. The column showing each operator's oil production for fiscal year 1975 (July l, 1974-June 30, 1975) indicates the magnitude of that operator's activities. The amount of oil production is only one factor in contrasting oil spills by operator. A complete analysis would, of course, consider many other factors, such as the amount of condensate production, the number of oil and condensate production platforms and the production per platform, the age of the fields and their production facilities, the types of spills, and the sources of spills (whether clustered at one field or scattered).

The 1- to 50-barrel production-platform incidents were tabulated (table 11) because these are the most frequent type of spill and the type which OCS Order No. 8 was designed to curtail. They also give some indication of the success of each operator's housekeeping programs. The individual trends for most operators correspond to the general trend (fig. 5) for production-platform spills. The number of spills generally declined between 1971 and 1975, with a consistent sharp decline in spills between 1971 and 1972. As expected, more spills are attributable to the large producers. No operator consistently contributed a disproportionate amount of spillage. The 1975 statistics are particularly encouraging: no single operator discharged more than 50 barrels.

The only 2 spills of more than 50 barrels in 1975 were related not to faulty operating practices on the platform but to workboat mishaps. In March a workboat bumped a platform and spilled 166 barrels of diesel fuel; and in September an anchor ship pulled an anchor too close to the drillship and ruptured a diesel fuel tank, spilling 100 barrels. 
Production Incidents, By Platform

The 536 chronic (1-50 barrels) production-platform incidents during 1971-75 were divided among 304 platforms (table 10). Figure 11 relates the number of structures having spills to the total number of fixed structures and the number of major structures. A major structure is defined as having two or more pieces of production equipment (vessels other than test separators) and (or) more than five producible completions. Nearly all the production incidents occurred at major platforms. In 1971 structures having spills represented 19 percent of the estimated number of major structures. That figure declined to 3.6 percent in 1974 and 4.2 percent in 1975.

To determine what percentage of the major platforms were actually producing or handling production from other platforms, the Gulf of Mexico platform file was examined. At the end of 1975 there were no producing wells on 117 of the 1,020 major platforms; 67 of these 117 nonproducing platforms were, however, being utilized for hydrocarbon separation and handling. Therefore, all but 50 (4.9 percent) of the major platforms were "candidates" for oil spillage at that time. The remaining 50 major platforms were in development-drilling or abandonment stages or were temporarily shut-in for mechanical reasons.

At the end of 1975, 1,202 structure complexes had at least 1 producing completion. The term "structure complex" is used because at some sites production equipment, personnel living quarters, and other facilities are separated onto several platforms attached by walkways. At the end of 1975 there were 1,786 complexes comprising 2,079 platforms. The ratio of the number of platforms with 1975 production spills (43) to the number of producing complexes at the end of 1975 was 0.036 (fig. 11).

of the 304 platforms having production spills during 1971-75, 188 platforms had only 1 spill (table 10). Thirteen platforms had at least 5 spills, with the maximum being 12. Of these 13 platforms, only 2 had more than 1 spill during 1974-75. Eight of the 13 had all their spills in 197173 and none in 1974-75. 


\section{OTHER SOURCES OF SPILLAGE}

Comparison of volume spilled to volume produced for Gulf of Mexico OCS Operations (drilling, production, and transportation) during 1971-75 discloses a spillage rate of 0.0028 percent. According to the council on Environmental Quality (1974) the historical spillage rate for tankers is 0.016 percent, more than 5 times the rate for Gulf of Mexico ocs operations. This estimate is for tankers of international registry, and it is generally accepted that U.S.-registration vessels have a better record. Furthermore, the development of deepwater ports, the application of new regulations restricting tanker discharges, and the application of new technology should significantly reduce the tanker-spillage rate.

The National Academy of Sciences (NAS) has estimated the sources of petroleum hydrocarbons entering the oceans (table 12; fig. 12). Only 1.3 percent of these hydrocarbons are attributed to offshore production. The NAS best estimate for annual discharges from offshore production is 0.08 million metric tons, or approximately 600,000 barrels. This estimate is 25 to 600 times the annual spillage for the Gulf of Mexico ocs in 1971-75. Almost two-thirds of the world's offshore production platforms, almost one-half of the world's offshore drilling activity, and approximately oneeighth of the offshore production occurred on the Gulf of Mexico OCS (1974 figures); thus, the NAS spillage estimate for offshore operations is by no means conservative and is probably somewhat too high. The NAS estimates that tanker discharges account for almost 2.13 million metric tons annually, or almost 16 million barrels. At present production rates, this equals the total oil and condensate production from the Gulf of Mexico ocs for 17 days.

The NAS also estimates that 0.6 million metric tons, or 4.5 million barrels, is discharged annually from natural seeps, more than 7 times the spillage attributed to offshore production. According to Fisher (1975), an estimated 70 thousand to 90 thousand barrels--the equivalent of the 1969 Santa Barbara spill and several times the maximum annual Gulf of Mexico spillage--seeps annually into Santa Barbara Channel waters. 
These figures give perspective to the broad problem of spills. They are not intended to minimize the potential for localized environmental disturbances from ocs activities or to excuse operations-related spillage or careless drilling and production practices; nonetheless, they do indicate that even if the hydrocarbon-discharge rate from operation activities approaches zero, tremendous volumes of hydrocarbons still will enter the oceans.

\section{CONCLUSIONS}

The spill statistics serve as a means of evaluating the effectiveness of U.S. Geological Survey regulatory programs and pinpointing problem areas and research needs. Also, the public should be informed on the nature of offshore oil and gas operations, including the potential for oil spills and other environmental impacts. The more detailed oil-spill data, together with the growing body of information on the biological impacts of crude discharges, will allow better cost-benefit analyses and a more rational evaluation of offshore oil and gas leasing programs.

The assumption is often made that the more severe oceanographic and meteorological conditions in frontier areas, such as the Gulf of Alaska and the North Atlantic, will cause more oil-spill incidents than have occurred in the Gulf of Mexico. This probably will not happen. Operators in these frontier areas will, from the outset, assess the resource potential by means of exploratory drilling. Very few spills have occurred during drilling and even fewer during exploratory drilling. No significant spillage has resulted from oil and gas operations in the harsh environment of the North Sea, where approximately 800 wells have already been drilled.

Development and production operations in the frontier areas will differ somewhat from those in the Gulf of Mexico. Owing to the tremendous costs of development, only major fields will be commercially exploited. Production facilities will more closely resemble those utilized in the North Sea than those operating in the Gulf of Mexico. In the Gulf of Mexico, more than 2,000 structures (many of which are single-well "satellites") are producing from over 1,600 oil reservoirs and approximately 1,200 gas reservoirs. Most of these reservoirs are small and have an 
average of less than two completed wells. Only 4 Gulf of Mexico fields produced an average of more than 50,000 BOPD (barrels of oil per day) during 1974--the Bay Marchand Block 2 Field (in State and Federal waters, South Timbalier area), West Delta Block 30 Field, Eugene Island Block 330 Field, and Grand Isle Block 43 Field. By contrast, fields in the North Sea are far fewer and much larger. At least 10 fields in just the British sector of the North Sea will have peak daily productions in excess of 50,000 barrels, 6 will exceed 100,000 BOPD, and at least 4 will ultimately produce more than 200,000 BOPD. North Sea steel and concrete towers are designed to accommodate a large number of wells and high production volumes. The $\$ 330$ million Brent B platform is expected to produce as much as 160,000 BOPD. Although the Gulf of Alaska and the Atlantic Coast areas probably will be less productive, large fields and North Sea-type structures will be necessary for commercial exploitation. The enormous size and expense of the facilities dictate that only the best production and safety equipment and operations personnel be used. The chance of failure is believed to be less because more production will be processed by less equipment. All safety and pollution-control equipment will be designed as an integral part of those platforms, rather than being added after many years of production. The redundancy which has been added to Gulf of Mexico systems will be original equipment for the frontier areas. Platform drainage systems will be fitted to the requirements of the structure, and no open sumps will be permitted. Pipeline systems will be protected by the latest cathodic protection systems and automatic volumetric sensors. New equipment is being developed for detecting pipeline corrosion by pumping special ultrasonic tools through the line. Reductions in the relative number and severity of oil spills in the frontier areas can reasonably be expected, should these areas prove productive.

Though continuing to seek a reduction in unnecessary discharges of oil and other liquid and solid waste materials from ocs structures, we must acknowledge the practical limitations to these discharge reductions. For example, there have been no indications of biological impacts from discharges of produced waters with an oil content of approximately 50 parts per million from ocs platforms. Such discharges quickly disperse to 
nontoxic levels in the low parts per billion range. Hydrocarbons present in these concentrations feed microbial oxidizers and may be beneficial. Some researchers determined, in laboratory experiments, that hydrocarbons present in seawater in concentrations less than 30 parts per billion actually stimulated phytoplankton growth (Gordon and Prouse, 1973). Lowering the hydrocarbon levels in formation-water discharges is technically feasible, but the resulting increase in costs and the loss in energy output are difficult to reconcile.

Although a cost-benefit approach may be both difficult and publicly unacceptable when the issues involve ocean-floor disturbances to sea life, conflicts with commercial fishing, and disturbances to onshore species and migratory fish and mammals, application of expensive restrictions should be preceded by demonstrable evidence that some benefit will indeed result. Efforts to protect valuable environmental resources have at times imposed restrictions based more on emotions than on scientific thought. Admittedly, restrictions against needless discharges must be diligently enforced, and additional environmental research and protection funds should be directed toward solving specific problems. In conjunction with the National Research Council Marine Board, Straughan (1975) outlined such a problem-oriented approach.

This report has presented statistics on one important problem associated with offshore oil and gas production. Similar statistical files will be developed to monitor operations in frontier areas. The frequency of inspections will be increased for initial exploratory operations in these areas. The causes of oil spillage in all offshore areas will be constantly examined, and efforts made to reduce them. Further modifications in the data system will better identify trouble areas.

\section{SELECTED REFERENCES}

Adams, M. V., John, C. B., Kelly, R. F., LaPointe, A. E., and Meurer, R. W., 1975, Mineral resource management of the Outer Continental Shelf: U.S. Geol. Survey Circ. 720, 32 p. [reprinted 1976].

Allen, A. A., and Schlueter, R. S., 1969, Estimates of surface pollution resulting from submarine oil seeps at Platform $A$ and Coal oil Point: Santa Barbara, Calif., General Research Corp. Tech. Memo. 1230, 43 p. 
Anderson, J. W., 1975, Laboratory studies on the effects of oil on marine organisms--An overview: Am. Petroleum Inst. Pub. 4249, 70 p.

Battelle Pacific Northwest Laboratories, 1973, Effects of oil and chemically dispersed oil on selected marine biota--A laboratory study: Am. Petroleum Inst. Pub. 4191, 104 p.

Fisher, P. J., 1975, Natural gas and oil seeps, Santa Barbara Basin, California: California State Univ. at Northridge, Dept. Geosciences, spec. rept. prepared for Natl. Oceanic and Atmospheric Admin., Sea Grants $04-3-158-45,04-5-158-20,37 \mathrm{p}$.

Fisher, P. J., and Stevenson, A. J., 1973, Natural hydrocarbon seeps along the northern shelf of the Santa Barbara Basin, California: Offshore Technology Conf., 5th Ann., Houston, Tex., 1973, Paper 1738, 10 p.

Garvey, Gerald, 1972, Energy, ecology, economy: New York, w. W. Norton and Co., 235 p.

Gordon, D. C., Jr., and Prouse, N. J., 1973, The effects of three different oils on marine phytoplankton photosynthesis: Dartmouth, Nova Scotia, Bedford Inst. Oceanography.

Harris, W. M., Piper, S. K., and McFarlane, B. E., compilers, 1976, Outer Continental Shelf statistics--oil, gas, sulfur, salt, leasing, drilling, production, income, 1953 through 1975, calendar year 1975: U.S. Geol. Survey Conservation Div. Spec. Rept., 91 p.

McCulloh, T. H., 1969, Geologic characteristics of the Dos Cuadras offshore oil field [California], in Geology, petroleum development, and seismicity of the Santa Barbara Channel region, California: U.S. Geol. Survey Prof. Paper 679-C, p. 29-46.

National Academy of Sciences, 1975, Petroleum in the marine environment--A report by the Ocean Affairs Board on the inputs, fates, and the effects of petroleum in the marine environment (Conf. at Airlie, Va., May 21-25, 1973): Natl. Acad. Sci., 107 p.

Sharp, J. M., and Tyson, J. W., compilers, 1974, The offshore ecology investigation--Final project planning council consensus report: Galveston, Tex., Gulf Universities Research Consortium (GURC) Rept. $138,39 \mathrm{p}$.

Smith, R. A., Slack, J. R., and Davis, R. K., 1976, An oilspill risk analysis for the Mid-Atlantic Outer Continental shelf lease area: U.S. Geol. Survey Open-File Rept. 76-451, 24 p.

Staff, Offshore (Magazine), 1975, Worldwide drilling and production report: v. 35 , no. 7 , p. 71-93. 
Straughan, Dale, 1971, Summary of biological effects of oil pollution in the Santa Barbara Channel, Part I: Allan Hancock Foundation, Southern California Univ., News Release, 9 p.

1972, Factors causing environmental changes after an oil spill: Jour. Petroleum Technology, v. 24, p. 250-254.

1975, Environmental studies as they relate to offshore petroleum operations, Appendix I, Fourth report of the review committee on safety of OCS petroleum operations: Natl. Research Council, Marine Board, p. 9-25.

(U.S.) Council on Environmental Quality, 1974, OCS oil and gas--An environmental assessment: Washington, Council Environmental Quality Rept. to the President, v. 1, 214 p.

U.S. Geological Survey, 1972, Outer Continental Shelf lease management study--Safety and pollution control: Washington, U.S. Geol. Survey Water Resources Div. Systems Lab. Group Rept., 116 p. 
F I G U R E S A N D T A B L E S 

Table 1.--Annual production (barrels) of oil and condensate

from all operations on the Outer Continental Shelf (OCS), 1971-75

\begin{tabular}{ccccc}
\hline \multirow{2}{*}{$\begin{array}{c}\text { Calendar } \\
\text { year }\end{array}$} & \multicolumn{2}{c}{ Gulf of Mexico ocs } & & Pacific ocs \\
\cline { 2 - 3 } & Louisiana & Texas & & Santa Barbara Channel \\
$1971 \ldots \ldots$ & $385,760,351$ & $1,685,047$ & & $31,103,548$ \\
$1972 \ldots \ldots$ & $387,590,662$ & $1,733,018$ & & $22,562,213$ \\
$1973 \ldots \ldots$ & $374,196,856$ & $1,617,829$ & & $18,915,314$ \\
$1974 \ldots \ldots$ & $342,435,496$ & $1,381,825$ & & $16,776,744$ \\
$1975 \ldots \ldots$ & $313,592,559$ & $1,340,136$ & & $15,304,757$ \\
\cline { 2 - 4 } Total..... & $1,803,575,924$ & $7,757,855$ & & $104,662,576$ \\
\hline
\end{tabular}

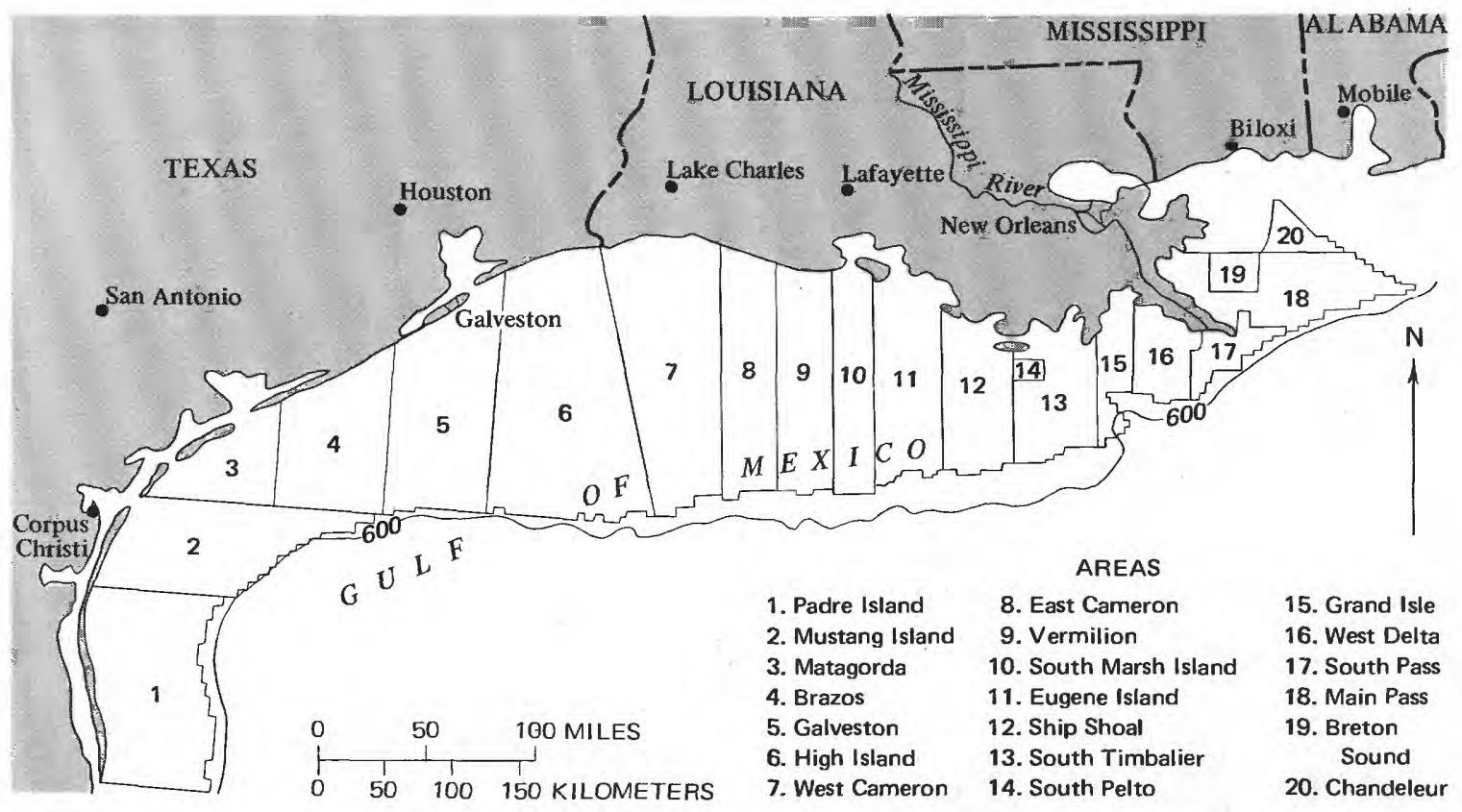

Figure 1.--Index map showing Outer Continental Shelf leasing areas off Texas and Louisiana. Line indicates 600-foot water depth. 


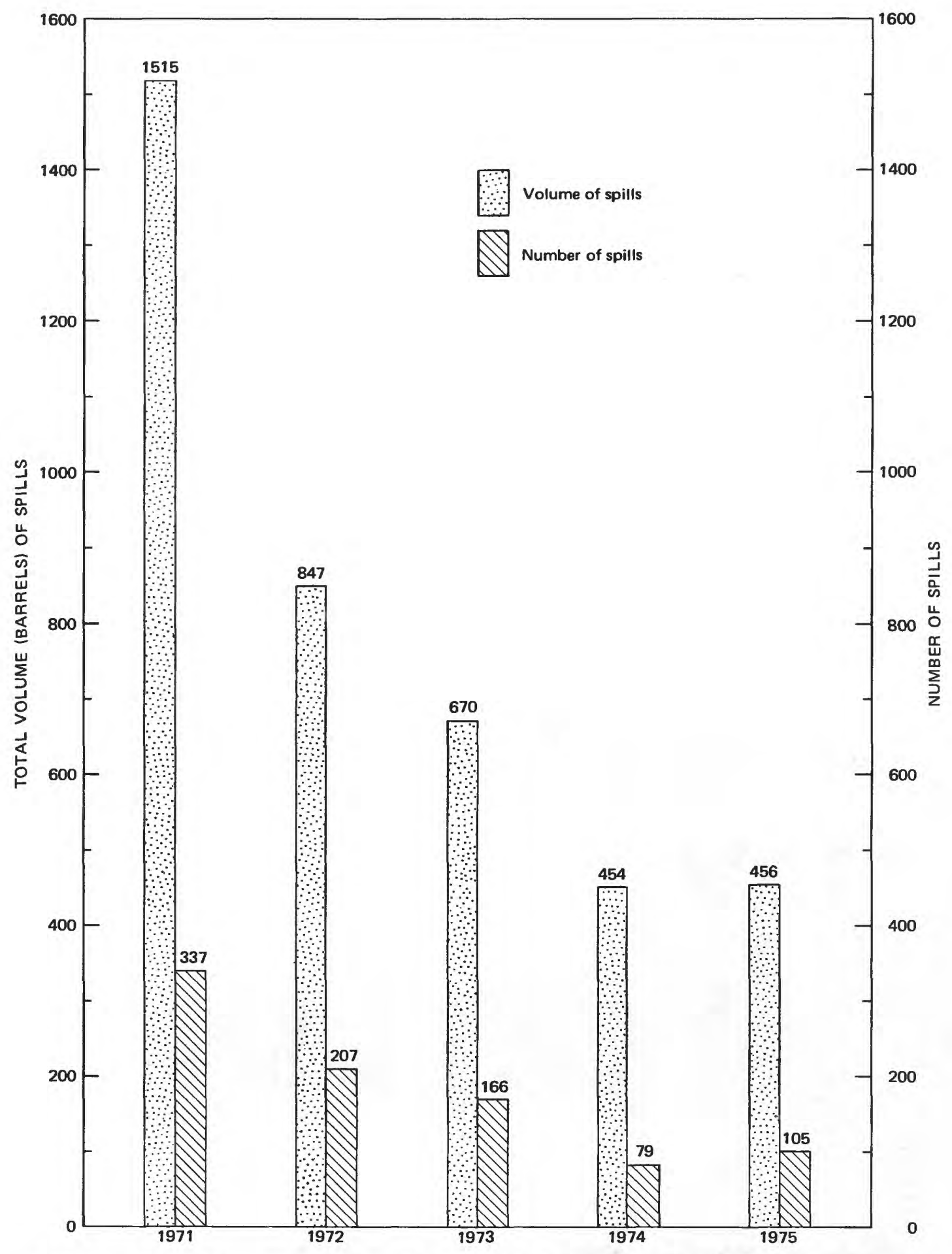

Figure 2.--Number and volume of 1- to 50-barrel spills by year, 1971-75, Gulf of Mexico Outer Continental Shelf. 


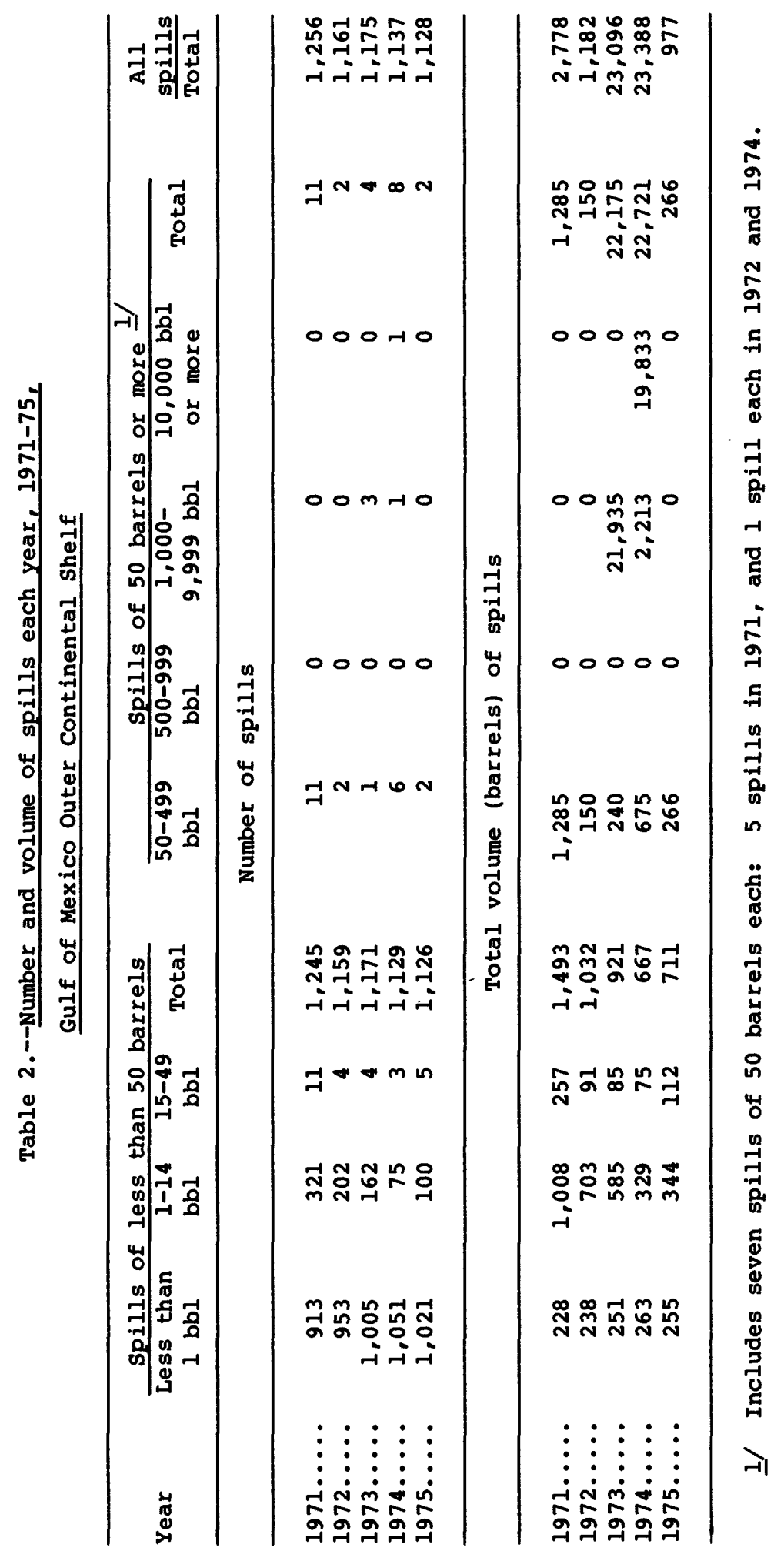


Table 3.--Causes of oil spills of more than 50 barrels, 1971-75,

Gulf of Mexico Outer Continental Shelf

\begin{tabular}{|c|c|c|c|c|}
\hline Cause & $\begin{array}{l}\text { Number } \\
\text { of spills }\end{array}$ & $\begin{array}{l}\text { Total } \\
\text { volume (bbl) }\end{array}$ & $\frac{\text { Volume (bb1) }}{\text { Maximum }}$ & $\frac{\text { per spill }}{\text { Minimum }}$ \\
\hline \multicolumn{5}{|l|}{ Production-platform equipment } \\
\hline malfunction or misuse............ & 6 & 10,925 & 9,935 & 75 \\
\hline Pipeline leaks and breaks.......... & 7 & 27,396 & 19,833 & 70 \\
\hline Drilling and workover mishaps...... & 0 & 0 & 0 & 0 \\
\hline oil transfer) $\ldots \ldots \ldots \ldots \ldots \ldots \ldots$ & 2 & 7,100 & 7,000 & 100 \\
\hline $\begin{array}{l}\text { Workboat spillage during unloading } \\
\text { of diesel fuel; or collision }\end{array}$ & & & & \\
\hline with platform................. & 3 & 506 & 240 & 100 \\
\hline Other causes.................. & 2 & 320 & 200 & 120 \\
\hline
\end{tabular}

Table 4.--Causes of oil spills of 1-50 barrels, 1971-75, Gulf of Mexico Outer Continental Shelf

\begin{tabular}{|c|c|c|c|c|c|}
\hline \multirow{2}{*}{ Cause } & \multirow{2}{*}{$\begin{array}{l}\text { Number } \\
\text { of spills }\end{array}$} & \multirow{2}{*}{$\begin{array}{c}\text { Total } \\
\text { volume (bbl) }\end{array}$} & \multicolumn{2}{|c|}{ Volume (bbl) $p$} & \multirow{2}{*}{$\frac{\text { per spill }}{m}$} \\
\hline & & & Average & Maximum & \\
\hline \multicolumn{6}{|l|}{ Production-platform equipment } \\
\hline malfunction or misuse............ & 536 & 2,286 & 4.26 & 50 & 1 \\
\hline Pipeline and pump failure......... & 232 & $1,105.5$ & 4.75 & 35 & 1 \\
\hline $\begin{array}{l}\text { Drilling and workover mishaps...... } \\
\text { Miscellaneous-equipment failures }\end{array}$ & 20 & 64.5 & 3.23 & 10 & 1 \\
\hline and employee errors............. & 84 & 440 & 5.24 & 36 & 1 \\
\hline
\end{tabular}




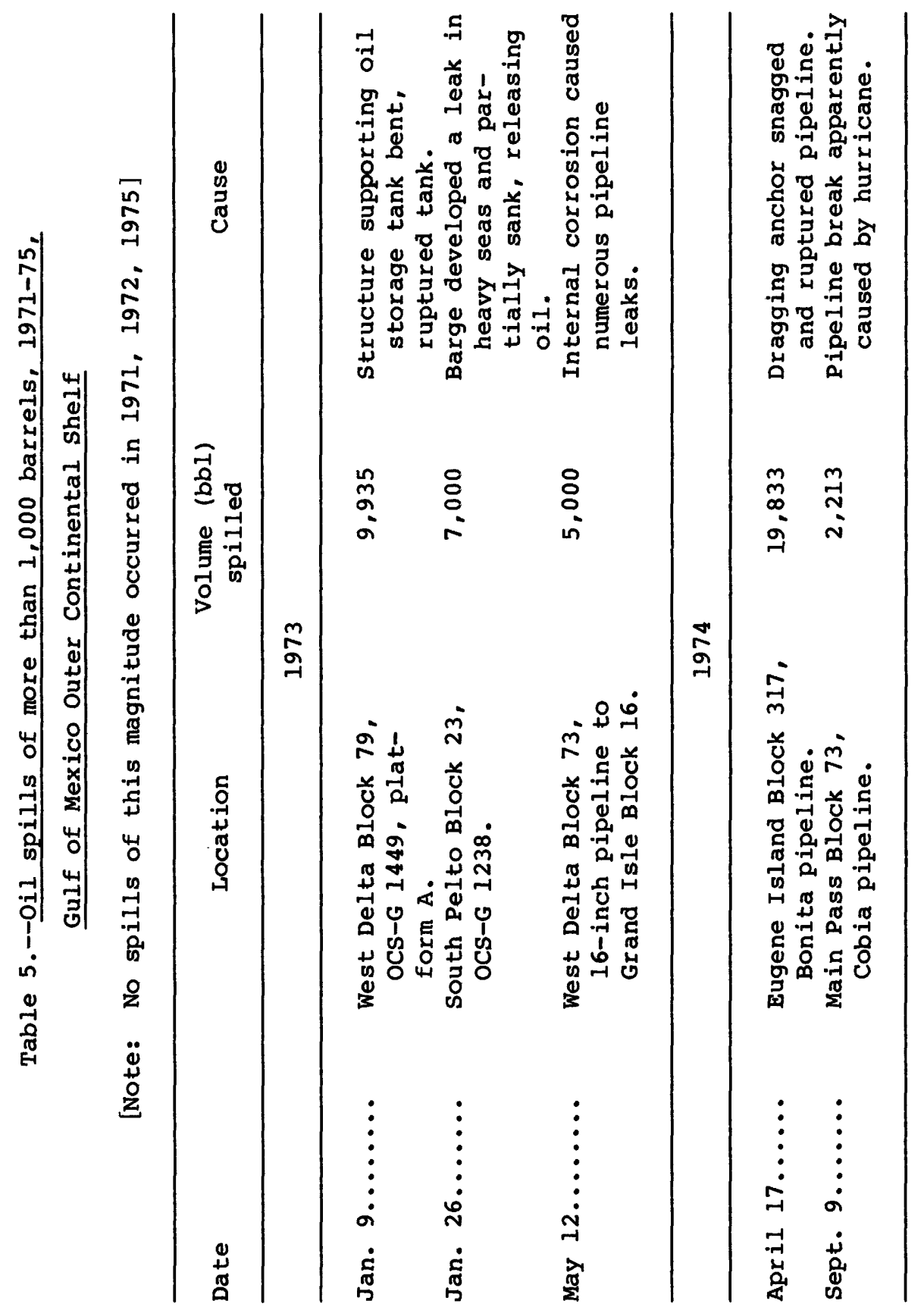


Table 6.--Blowouts resulting in pollution, casualties, or property damage, 1971-75, Gulf of Mexico Outer Continental Shelf

\begin{tabular}{|c|c|c|c|c|}
\hline Date & Location & $\begin{array}{l}\text { Type of } \\
\text { accident }\end{array}$ & $\begin{array}{l}\text { Volume } \\
\text { (bbl) } \\
\text { spilled }\end{array}$ & $\begin{array}{c}\text { Casualties, property } \\
\text { damage }\end{array}$ \\
\hline \multicolumn{5}{|c|}{ Blowouts during drilling } \\
\hline $\begin{array}{l}\text { March 3-6, } \\
\quad 1971\end{array}$ & $\begin{array}{l}\text { West Cameron } \\
\text { Block } 639 \text {, } \\
\text { ocs-G } 2027 \text {, } \\
\text { well } 1 \text {. }\end{array}$ & $\begin{array}{l}\text { Gas blowout, at well } \\
\text { depth } 3,956 \mathrm{ft} \text {. }\end{array}$ & 0 & $\begin{array}{l}\text { Blowout-preventer } \\
\text { assembly and drill } \\
\text { pipe lost; well } \\
\text { lost. }\end{array}$ \\
\hline $\begin{array}{l}\text { Dec. 3-5, } \\
1972\end{array}$ & $\begin{array}{l}\text { South Pass } \\
\text { Block } 78 \\
\text { ocs-G } 2185 \\
\text { well } 2\end{array}$ & $\begin{array}{l}\text { Gas blowout, } 3,850 \mathrm{ft} . ; \\
\text { last string of } \\
\text { casing set at } \\
1,018 \mathrm{ft} .\end{array}$ & 0 & $\begin{array}{l}\text { Rig collapsed and was } \\
\text { lost in crater. }\end{array}$ \\
\hline $\begin{array}{l}\text { May } 5-26 \\
1973\end{array}$ & $\begin{array}{l}\text { South Marsh Island } \\
\text { Block 268, } \\
\text { OCs-G 2310, } \\
\text { well } 2 \text {. }\end{array}$ & $\begin{array}{l}\text { Gas blowout during } \\
\text { drilling, depth } \\
11,393 \mathrm{ft} \text {. }\end{array}$ & 0 & Well lost. \\
\hline $\begin{array}{l}\text { Oct. } 1-2 \text {, } \\
1973\end{array}$ & $\begin{array}{l}\text { West Cameron } \\
\text { Block 543, } \\
\text { ocs-G 2010, } \\
\text { platform A, } \\
\text { well A-4. }\end{array}$ & $\begin{array}{l}\text { Blowout, explosion, } \\
\text { and fire; gas; well } \\
\text { depth } 8,540 \mathrm{ft} \text {. }\end{array}$ & 0 & $\begin{array}{l}\text { Three men injured } \\
\text { slightly; all } \\
\text { platform equipment } \\
\text { destroyed or badly } \\
\text { damaged. }\end{array}$ \\
\hline $\begin{array}{l}\text { March 19, } \\
1975\end{array}$ & $\begin{array}{l}\text { High Island } \\
\text { Block A-471, } \\
\text { OCS-G 2690, } \\
\text { well } 1 .\end{array}$ & Gas blowout, $1,150 \mathrm{ft}$. & 0 & Well and rig lost. \\
\hline \multicolumn{5}{|c|}{ Blowouts during nondrilling operations } \\
\hline $\begin{array}{l}\text { Oct. 16- } \\
\text { Dec. 10, } \\
1971\end{array}$ & $\begin{array}{l}\text { Eugene Island } \\
\text { Block } 215, \\
\text { OCs-0678, } \\
\text { platform B. }\end{array}$ & $\begin{array}{l}\text { Explosion and fire at } \\
\text { oil pump. }\end{array}$ & 450 & $\begin{array}{l}\text { Production platform } \\
\text { and equipment } \\
\text { lost. }\end{array}$ \\
\hline $\begin{array}{c}\text { June } 10 \\
1974\end{array}$ & $\begin{array}{l}\text { South Pelto } \\
\text { Block 20, } \\
\text { ocs 073, } \\
\text { platform 13, } \\
\text { well } 13 .\end{array}$ & $\begin{array}{l}\text { Casing valve broke } \\
\text { off wellhead } \\
\text { during hurricane. }\end{array}$ & 75 & None. \\
\hline $\begin{array}{l}\text { Dec. } 22- \\
31,1974\end{array}$ & $\begin{array}{l}\text { South Pelto } \\
\text { Block 19, } \\
\text { ocs 073, } \\
\text { platform 12, } \\
\text { well } 12 .\end{array}$ & $\begin{array}{l}\text { Casing and tubing } \\
\text { sheared at mudline } \\
\text { during hurricane- } \\
\text { damage repair. }\end{array}$ & 200 & None. \\
\hline $\begin{array}{c}\text { June } 12 \\
1975\end{array}$ & $\begin{array}{l}\text { South Marsh Island } \\
\text { Block 50, } \\
\text { Ocs 0788, } \\
\text { platform B. }\end{array}$ & $\begin{array}{l}\text { Well blew out during } \\
\text { completion operations. } \\
\text { Gas burned for } 2 \text { days. }\end{array}$ & (1/) & $\begin{array}{l}\text { Platform drilling deck } \\
\text { and equipment } \\
\text { damaged by fire. }\end{array}$ \\
\hline
\end{tabular}

1/ Some condensate was discharged as a result of this incident. When the platform is repaired, production is begun, and more reservoir data are obtained, spillage will be estimated. 


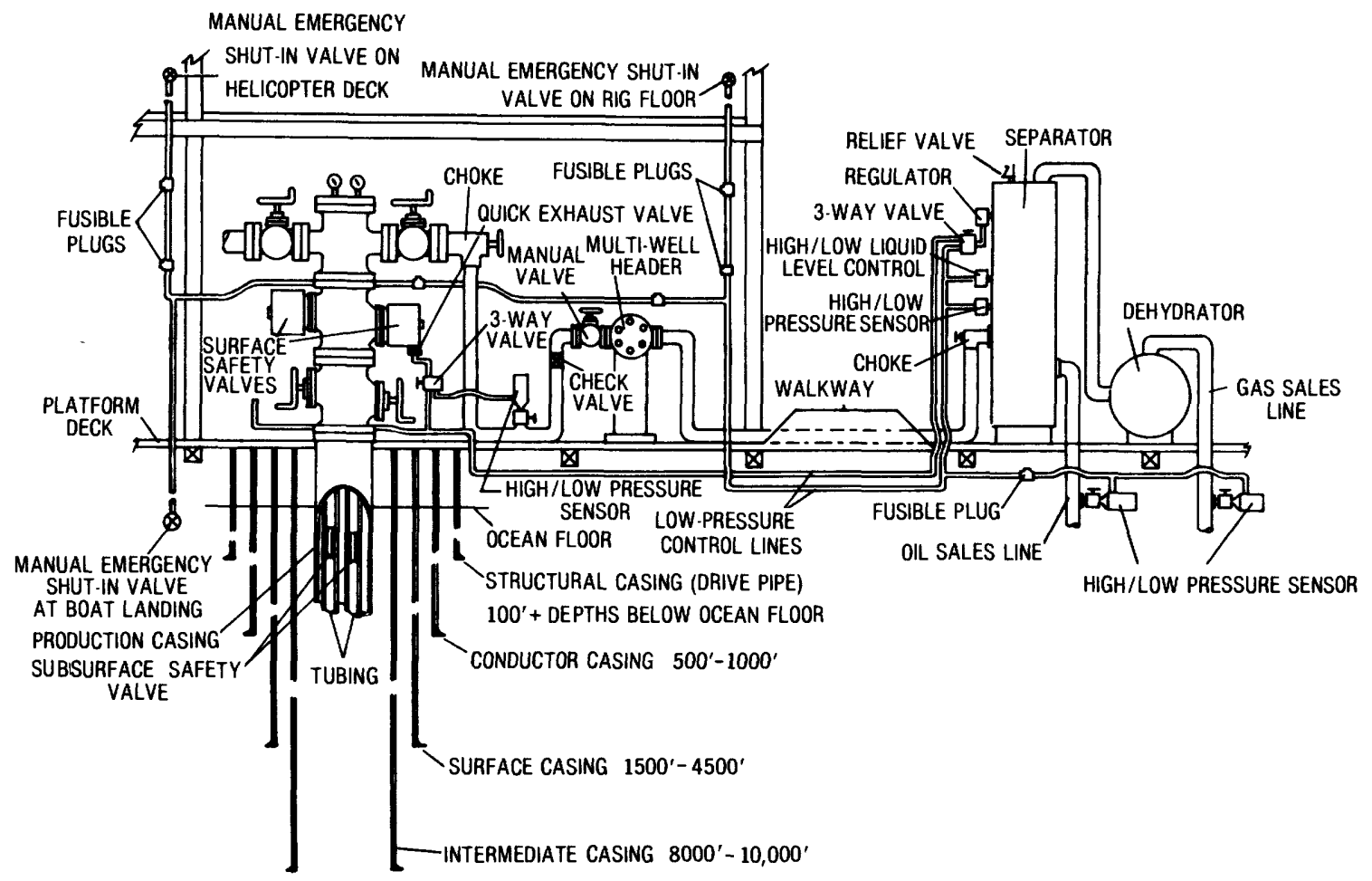

Figure 3.--Schematic diagram showing casing program and production safety system of a typical 12,000-foot-deep well, Gulf of Mexico.

Table 7.--Causes of 1- to 50-barrel spills on production platforms, 1971-75, Gulf of Mexico Outer Continental Shelf

[Note: Some incidents fall in more than one category, and therefore the total shown here exceeds the total number of production-platform spills shown in table 4. Also, the individual totals for the first three categories shown here are less than the sums of the itemized entries in table 8]

\begin{tabular}{|c|c|c|c|c|c|}
\hline \multirow[b]{2}{*}{ System that failed } & \multirow{2}{*}{$\begin{array}{c}\text { Number } \\
\text { of } \\
\text { spills }\end{array}$} & \multirow{2}{*}{$\begin{array}{l}\text { Total } \\
\text { volume } \\
\text { (bbl) }\end{array}$} & \multirow{2}{*}{$\frac{\text { Volume }}{\text { Average }}$} & \multirow{2}{*}{ 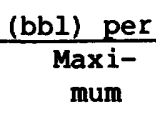 } & \multirow{2}{*}{ 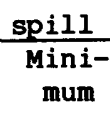 } \\
\hline & & & & & \\
\hline sump system................... & 159 & 627.5 & 3.95 & 50 & 1 \\
\hline other hydrocarbon-handling equipment.... & 139 & 695 & 5.00 & 50 & 1 \\
\hline separator system................. & 113 & 407 & 3.60 & 50 & 1 \\
\hline Well and header system............... & 85 & 473 & 5.56 & 50 & 1 \\
\hline Flare line system.................. & 54 & 188.5 & 3.49 & 30 & 1 \\
\hline Heater treater system.............. & 24 & 92.5 & 3.85 & 10 & 1.5 \\
\hline
\end{tabular}




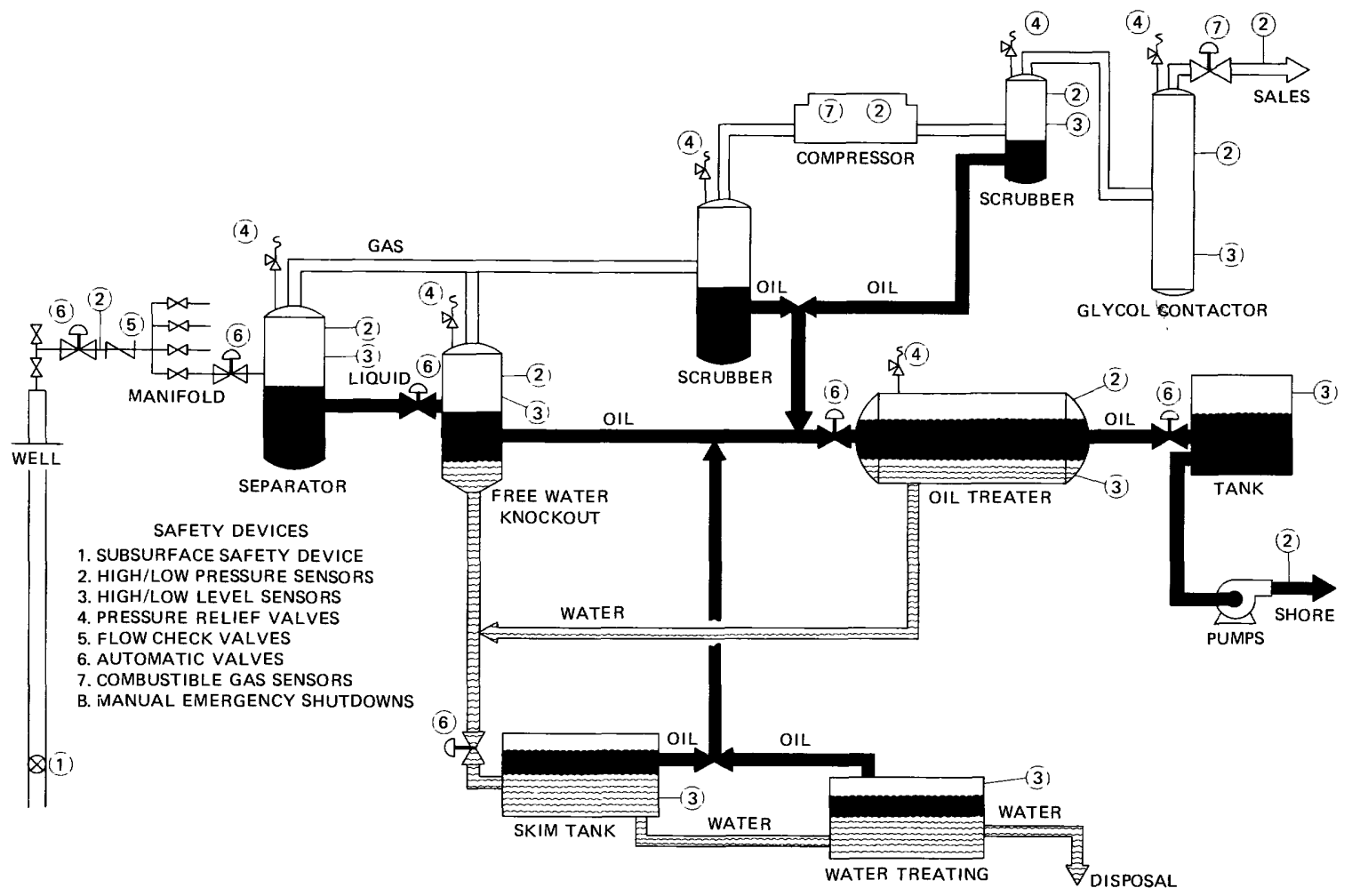

Figure 4.--Simplified flow diagram for offshore oil and gas production. 

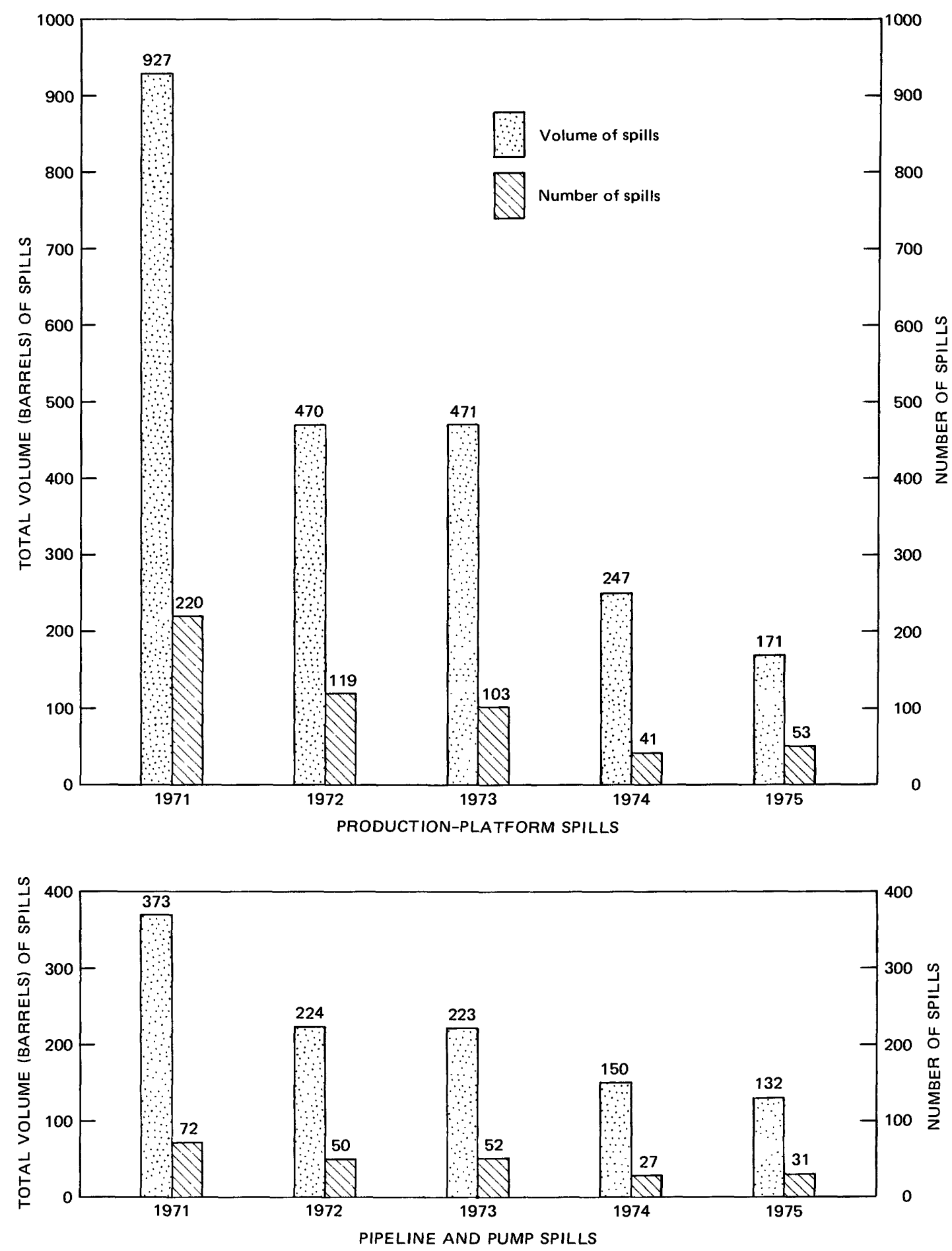

Figure 5.--Number and volume of 1- to 50-barrel spills, by year, 1971-75, for production platforms and for pipelines and pumps, Gulf of Mexico Outer Continental Shelf. 
Table 8.--Causes of 1- to 50-barrel spills on production platforms, 1971-75, Gulf of Mexico Outer Continental Shelf, grouped according to system that failed

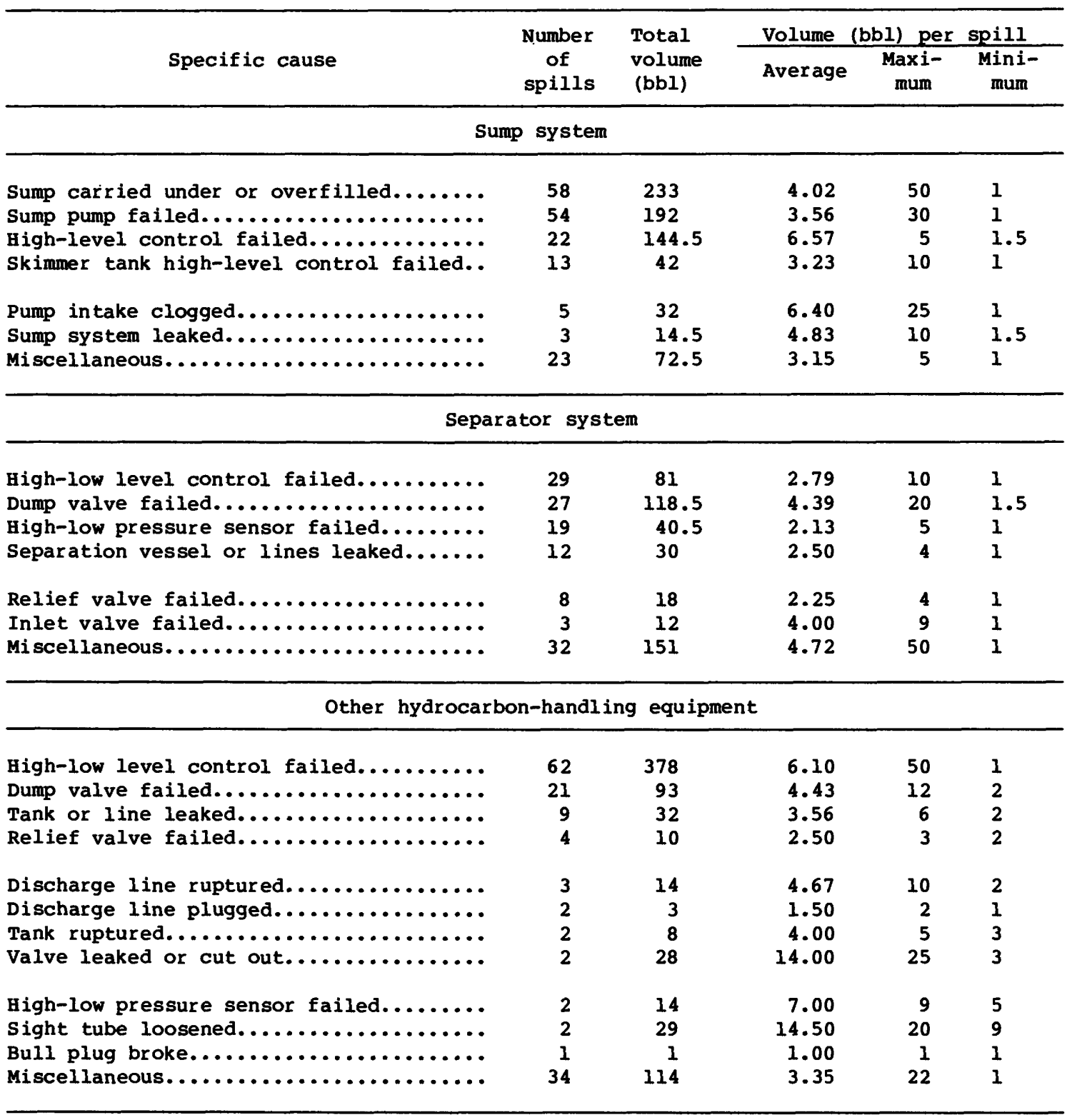




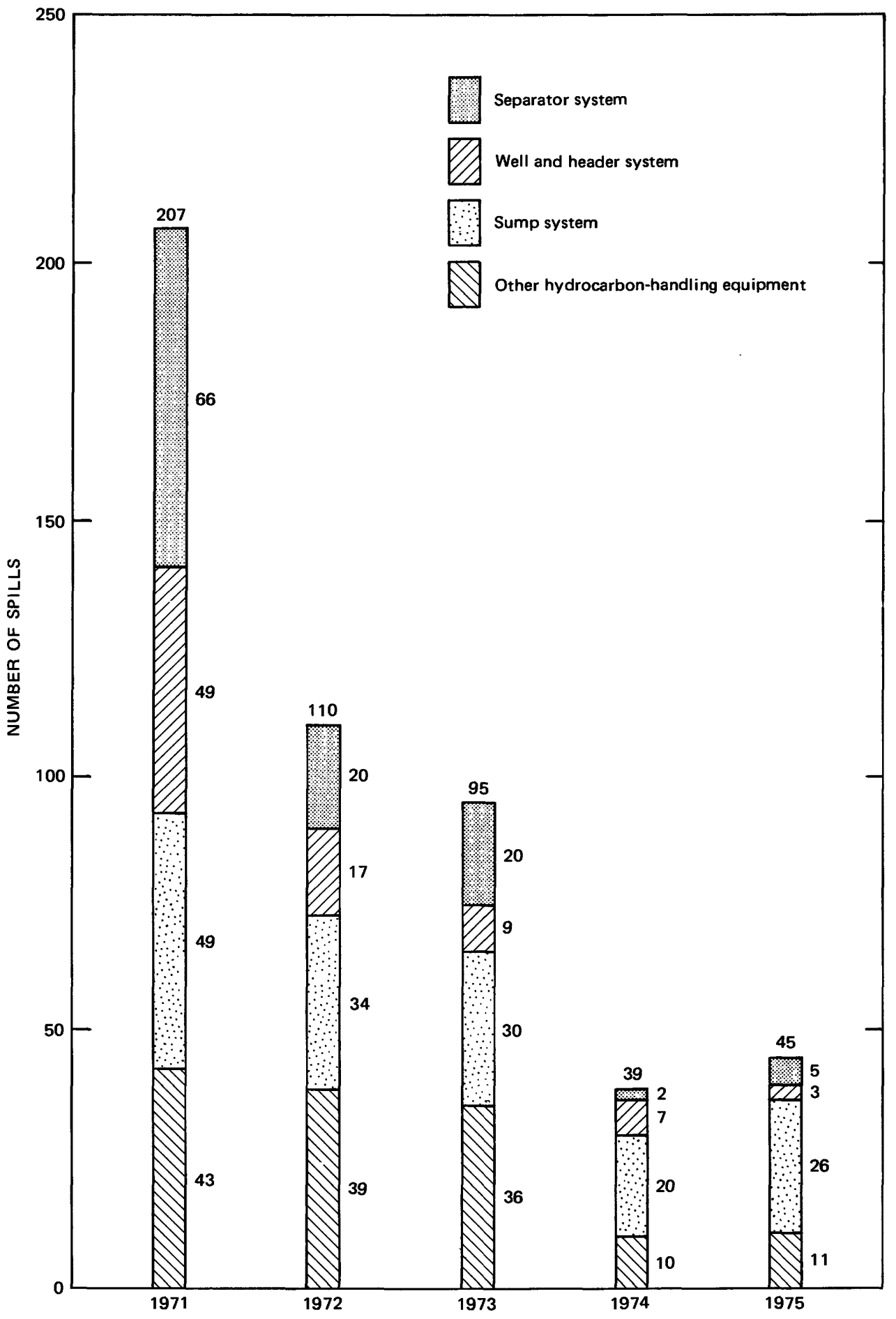

Figure 6.--Principal causes of production-platform spills of 1-50 barrels, by year and number of spills, 1971-75, Gulf of Mexico Outer Continental shelf. 


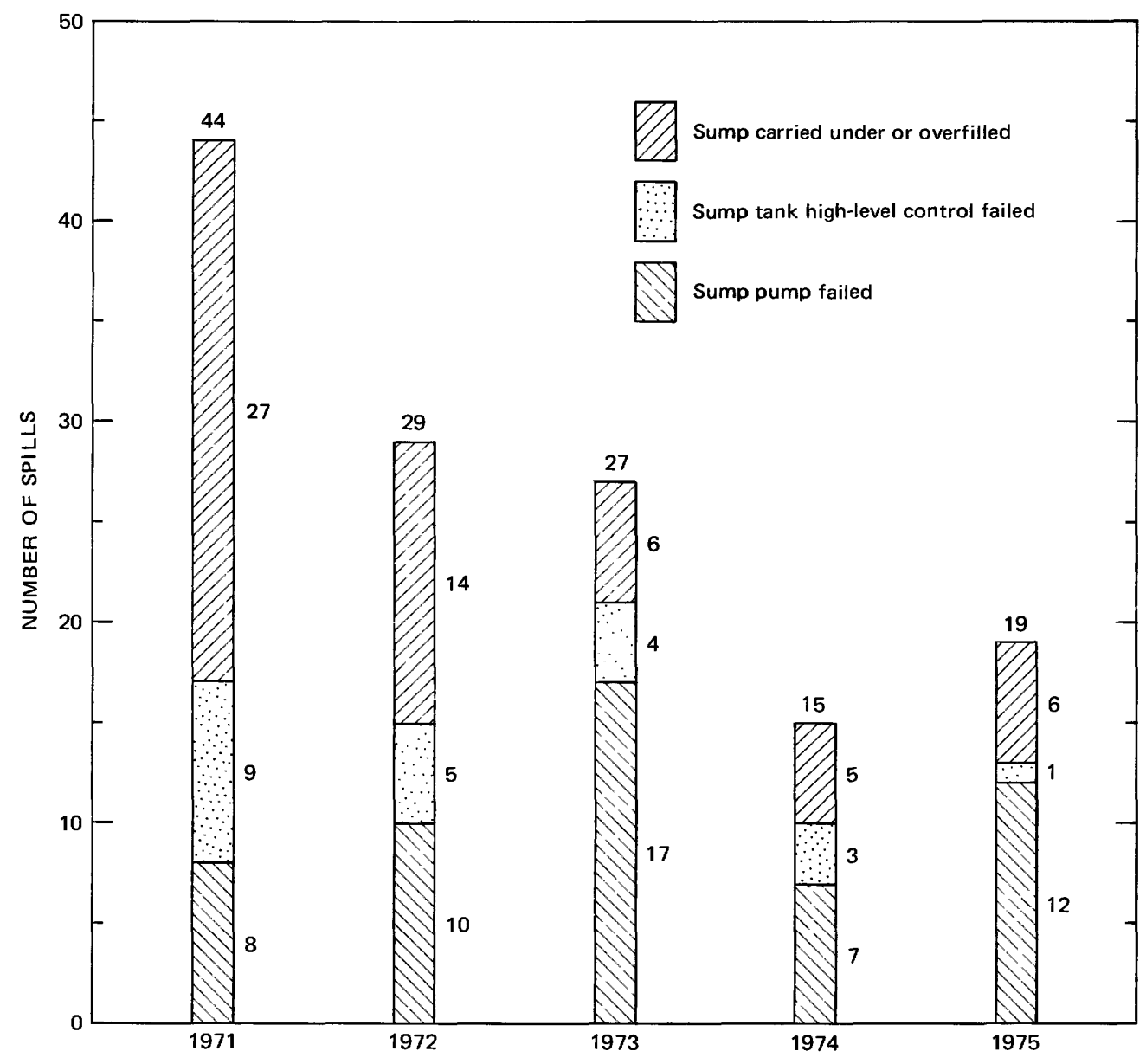

Figure 7.--Principal causes of sump-system spills of 1-50 barrels on production platforms, by year and number of spills, 1971-75, Gulf of Mexico Outer Continental Shelf. 


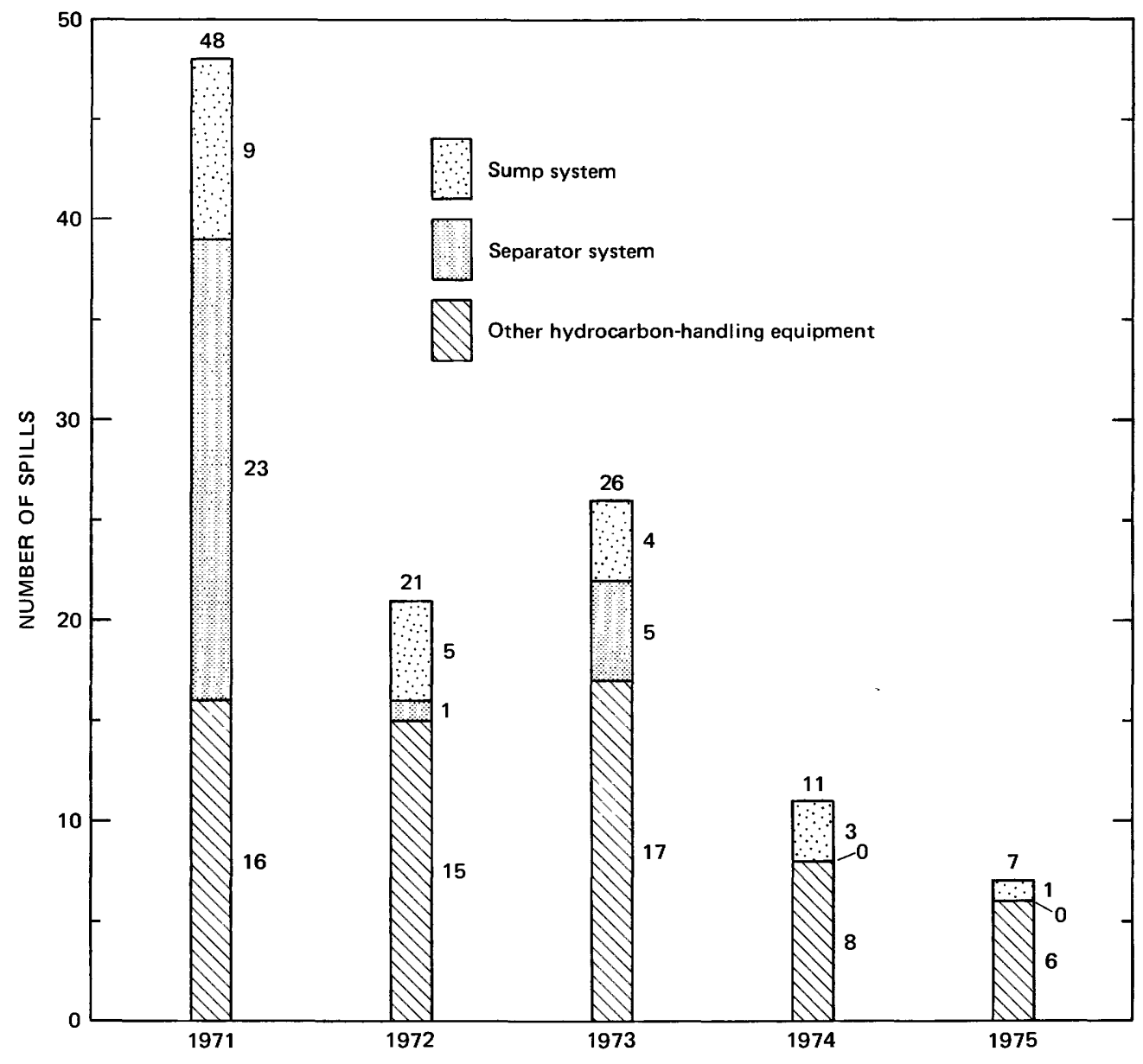

Figure 8.--Number of 1- to 50-barrel spills involving failures of high-low level controls on production platforms, by year, 1971-75, Gulf of Mexico Outer continental shelf. 


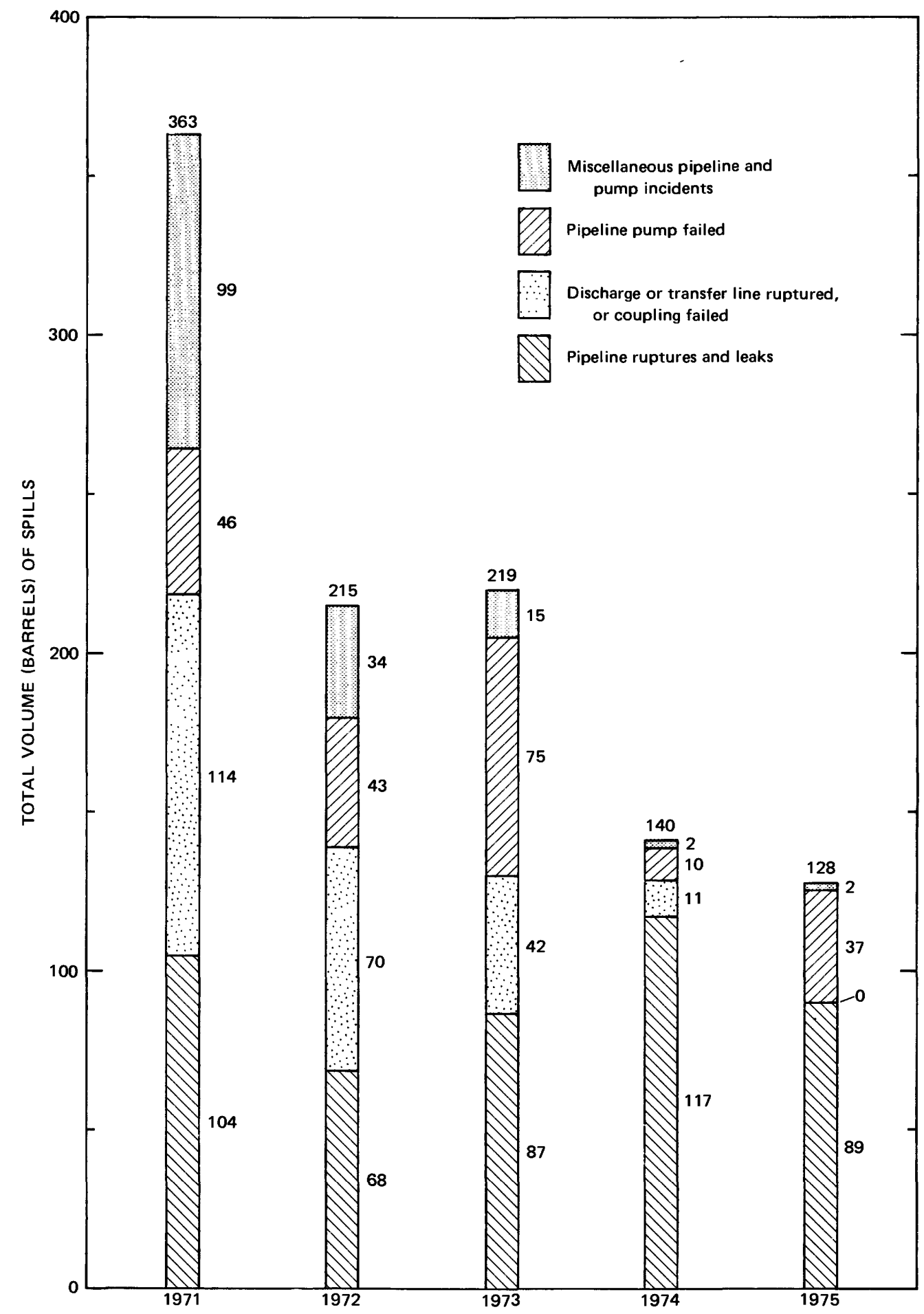

Figure 9.--Principal causes of pipeline and pump spills of 1-50 barrels, by year and volume of spills, 1971-75, Gulf of Mexico Outer Continental Shelf. 


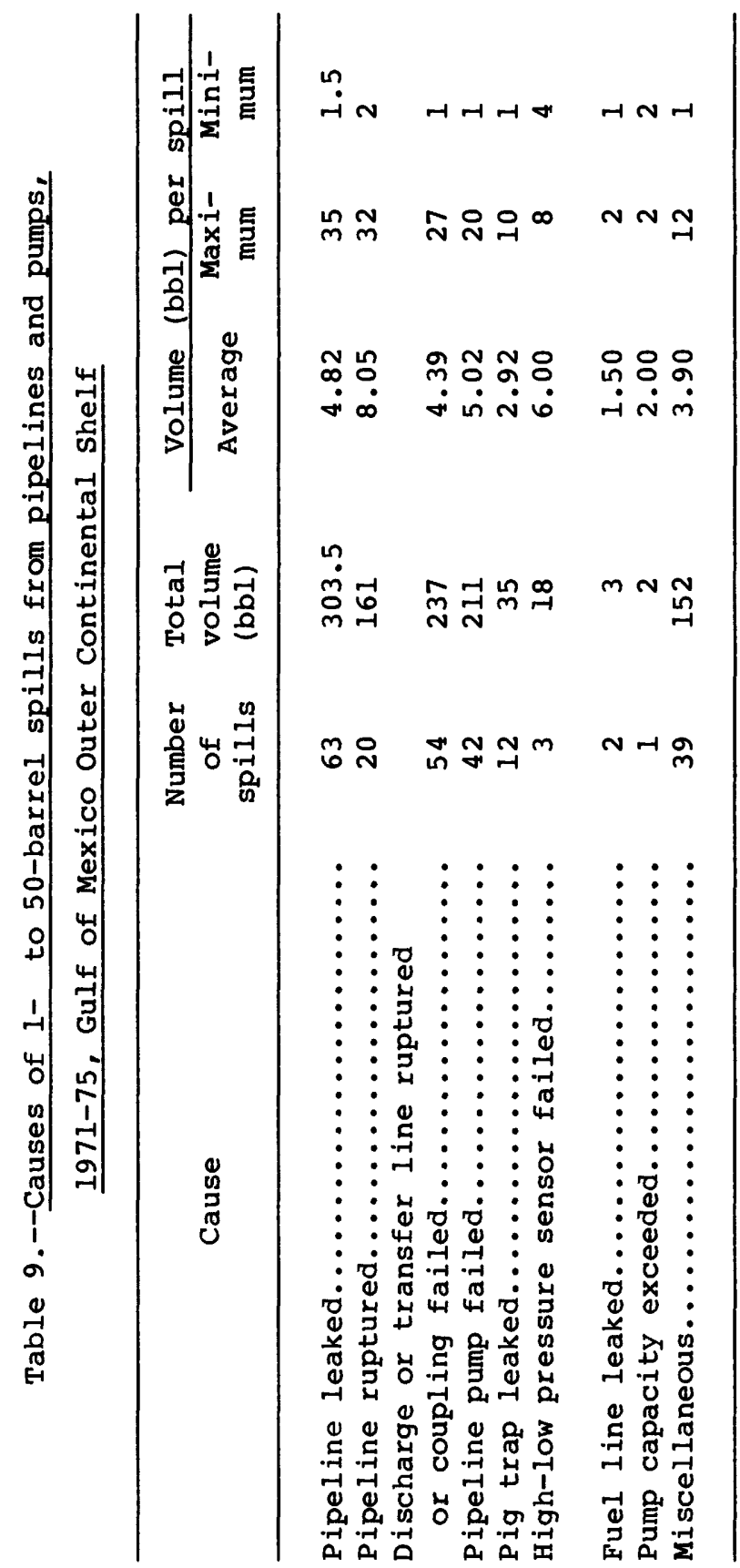


Table 10.--Frequency of spills among production platforms

having at least one 1- to 50-barrel spill, 1971-75,

Gulf of Mexico Outer Continental Shelf

\begin{tabular}{cc||cc}
\hline $\begin{array}{l}\text { Number of } \\
\text { spills per } \\
\text { platform }\end{array}$ & $\begin{array}{c}\text { Number of } \\
\text { platforms having } \\
\text { spills }\end{array}$ & $\begin{array}{c}\text { Number of } \\
\text { spills per } \\
\text { platform }\end{array}$ & $\begin{array}{c}\text { Number of } \\
\text { platforms having } \\
\text { spills }\end{array}$ \\
\hline$\ldots \ldots$ & 188 & $7 \ldots \ldots$ & 4 \\
$2 \ldots \ldots$ & 67 & $8 \ldots \ldots$ & 0 \\
$3 \ldots \ldots$ & 23 & $9 \ldots \ldots$ & 1 \\
$4 \ldots \ldots$ & 13 & $10 \ldots \ldots$ & 0 \\
$5 \ldots \ldots$ & 4 & $11 \ldots \ldots$ & 1 \\
$6 \ldots$ & 3 & $12 \ldots \ldots$ & 1 \\
& & & Total..... \\
\hline
\end{tabular}




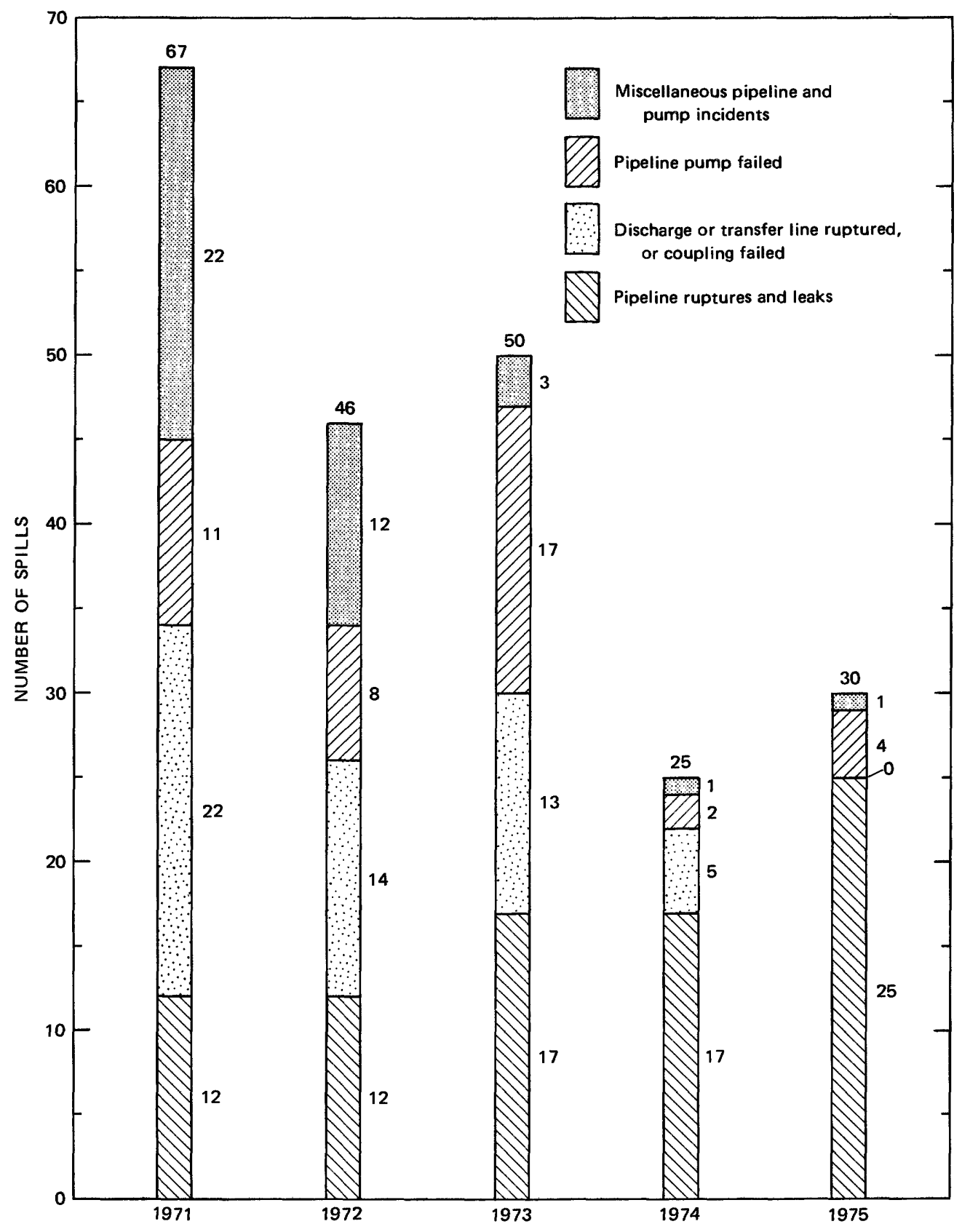

Figure 10.--Principal causes of pipeline and pump spills of 1-50 barrels, by year and number of spills, 1971-75, Gulf of Mexico Outer Continental shelf. 


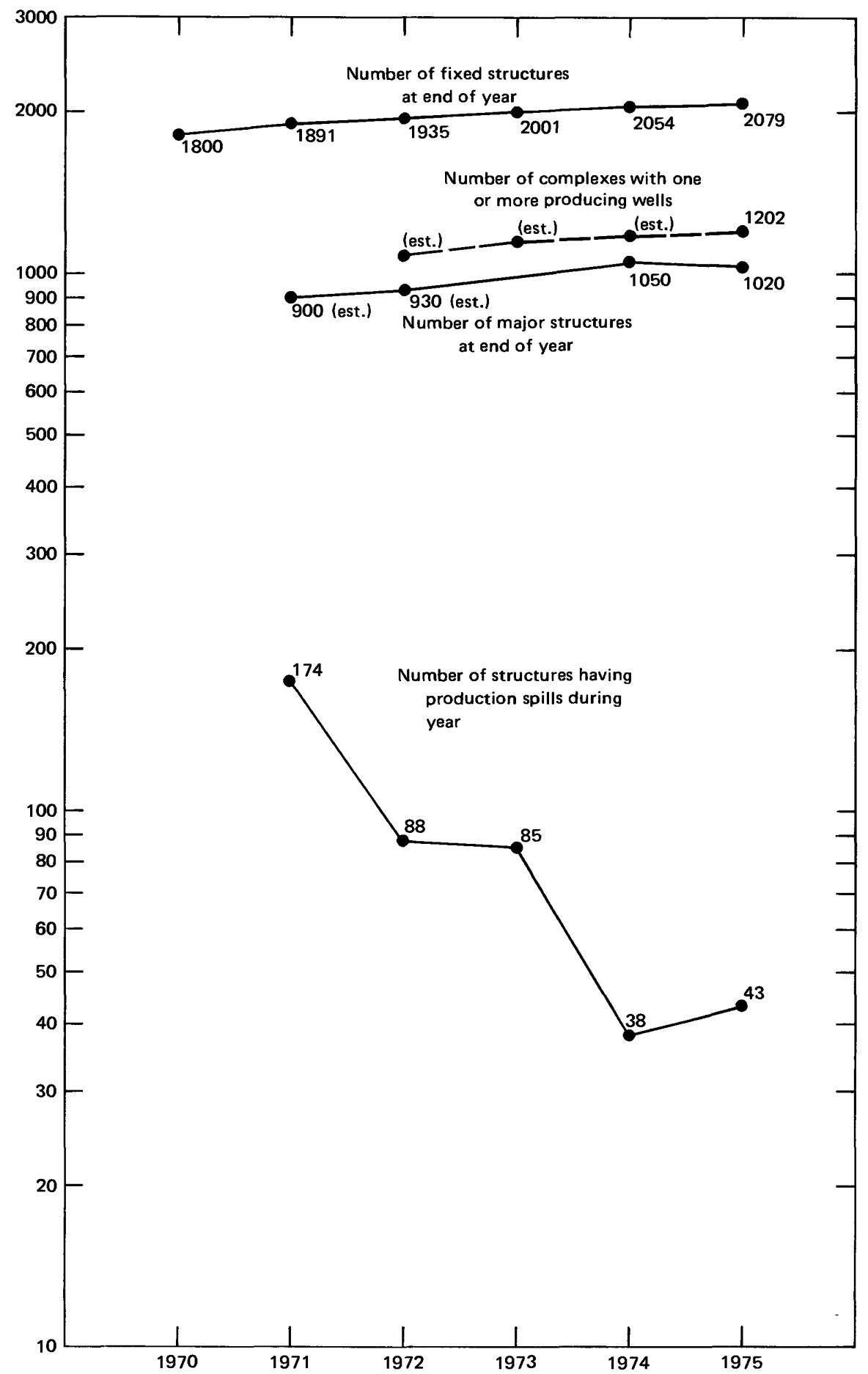

Figure 11.--Comparison, by year, of the number of structures having spills with the total number of fixed and major structures. A major structure is defined as having two or more pieces of production equipment and (or) more than five producible completions. 


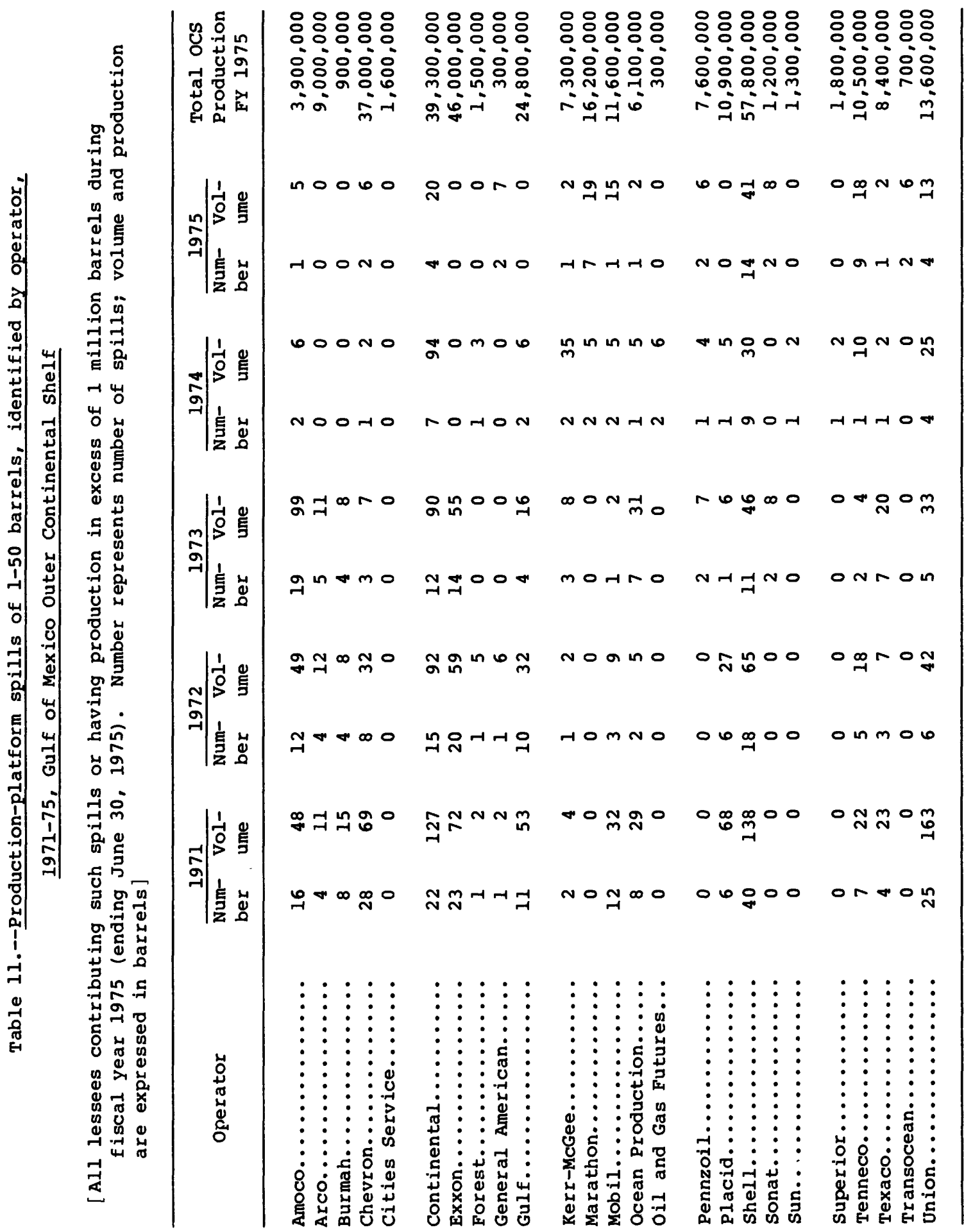




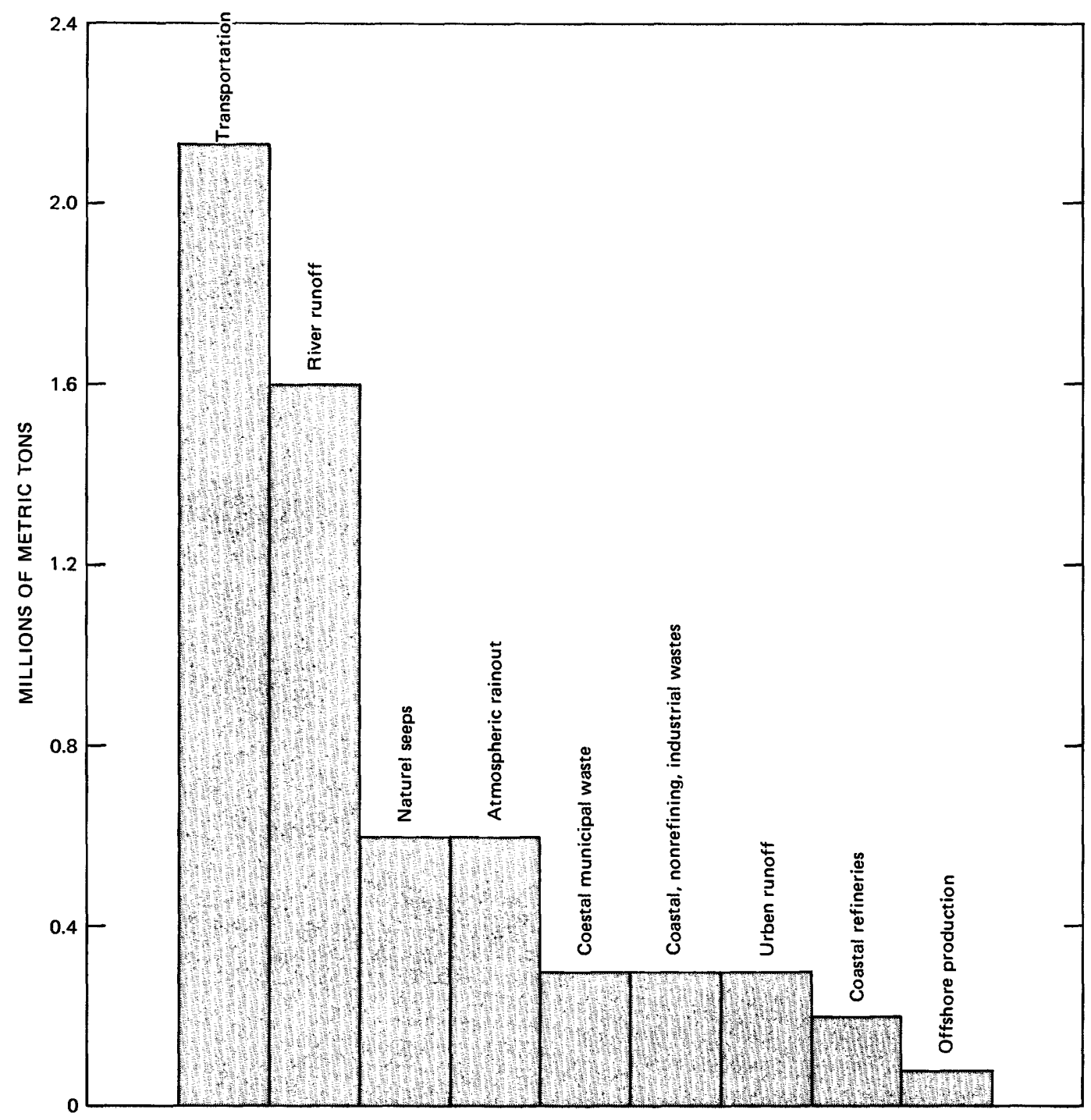

Figure 12.--Estimated volumes of petroleum hydrocarbons introduced annually into the world's oceans, in millions of metric tons. Numerical breakdown of categories is shown in table 12 . 


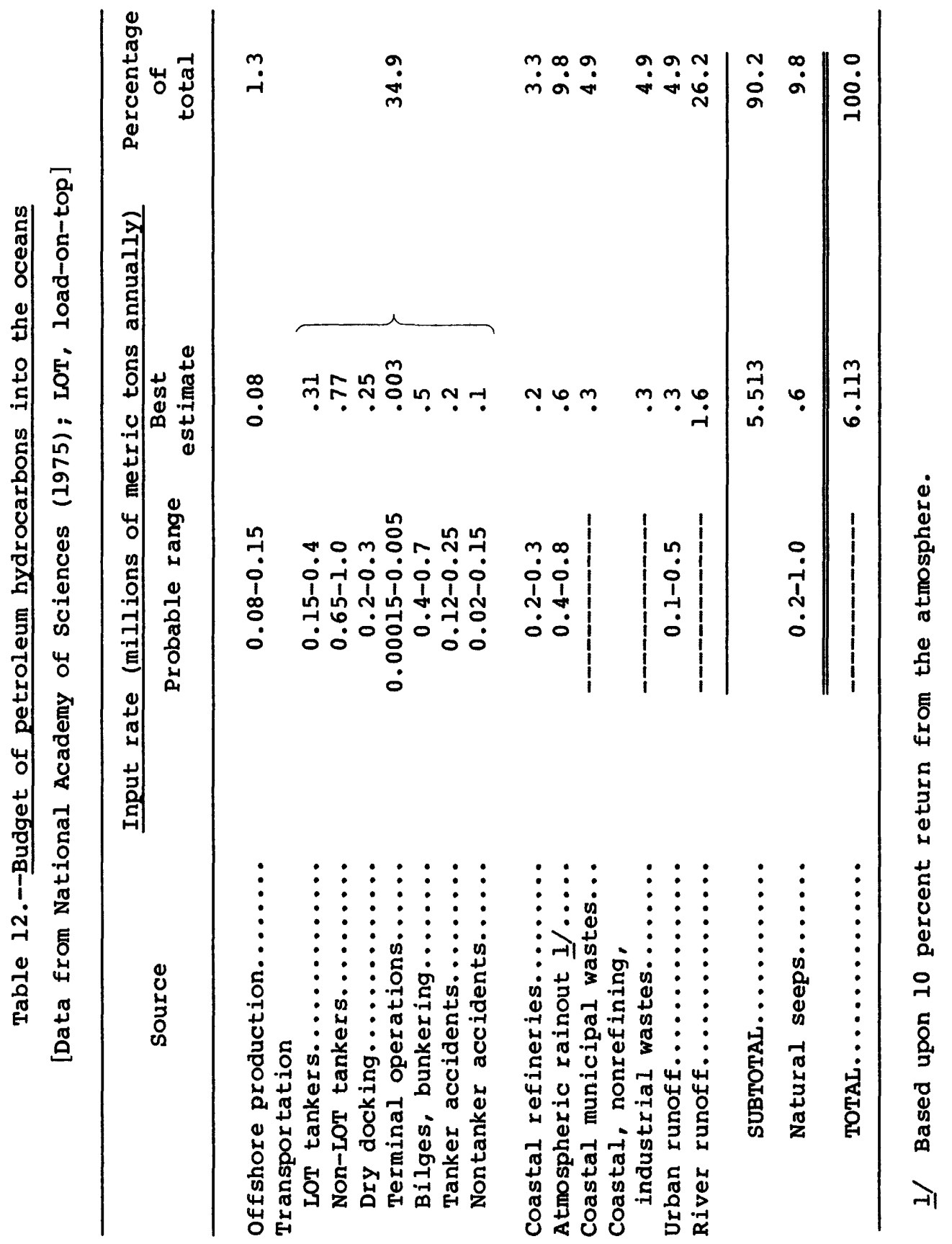


